\title{
SPRAWL BECAUSE OF YOU:
}

\section{THE EMERGENCE OF SMART GROWTH POLICY IN CALGARY, ALBERTA}

$$
\text { By: }
$$

\author{
Chris Andrew \\ B.Mgt, University of Lethbridge, 2009 \\ A Major Research Paper \\ presented to Ryerson University \\ in partial fulfillment of the requirements for the degree of \\ Master of Planning \\ In \\ Urban Development
}

Toronto, Ontario, Canada, 2015

(c) Chris Andrew 2015 


\section{Author's Declaration for Electronic Submission of a MRP}

I hereby declare that I am the sole author of this MRP. This is a true copy of the MRP, including any required final revisions. I authorize Ryerson University to lend this MRP to other institutions or individuals for the purpose of scholarly research

I further authorize Ryerson University to reproduce this MRP by photocopying or by other means, in total or in part, at the request of other institutions or individuals for the purpose of scholarly research.

I understand that my MRP may be made electronically available to the public. 


\title{
SPRAWL BECAUSE OF YOU:
}

\section{THE EMERGENCE OF SMART GROWTH POLICY IN CALGARY, ALBERTA}

\author{
(C) Chris Andrew 2015
}

\author{
Master of Planning \\ In \\ Urban Development \\ Ryerson University
}

\begin{abstract}
This paper analyzes whether Smart Growth policies, embedded within the City of Calgary's Municipal Development Plan, have been successful in battling sprawl and progressing towards the overarching goals of Smart Growth. A review of the literature and a historical review of urban sprawl in Calgary establishes a set of indicators demonstrating that the city is struggling to progress towards the goals of Smart Growth. While there are encouraging findings, the paper recommends the potential implementation of policy changes to ensure that The City is wellpositioned to combat sprawl going forward.
\end{abstract}

Key Words: City of Calgary, Smart Growth, Urban Policy, Urban Sprawl, Density 


\section{Acknowledgements}

I would like to acknowledge my supervisor, Dr. Jaclene Begley for her guidance and assistance on this paper. In addition, I would like to thank my second reader, Mary Axworthy from the University of Calgary, for her subject matter expertise and comprehensive input.

The last two years would be nothing without the perspectives, personalities, and ideas contributed by my peers. I have enjoyed working with you all and thank you for letting me speak endlessly about, well, you all know what city.

Thank you to all my family and friends who have supported me throughout these exciting and turbulent times. I went "all in" on this journey and I appreciate those individuals who understand how important these last two years have been for me.

A round of applause to you all. Thank you. 


\section{Table of Contents}

Author's Declaration for Electronic Submission of a MRP .................................................................ii

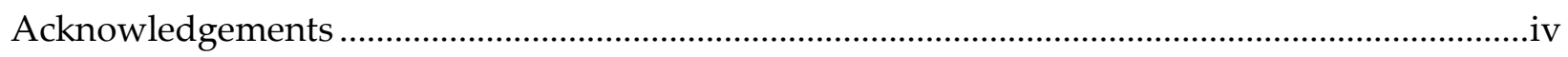

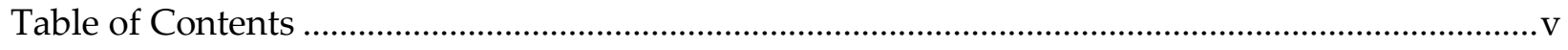

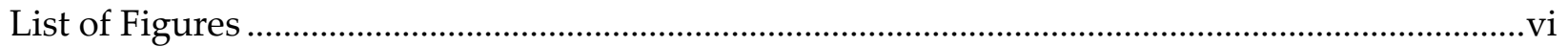

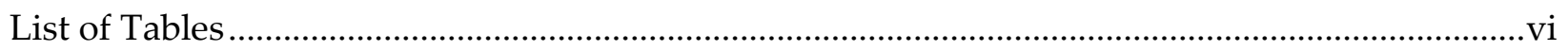

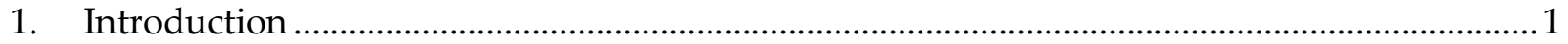

Purpose

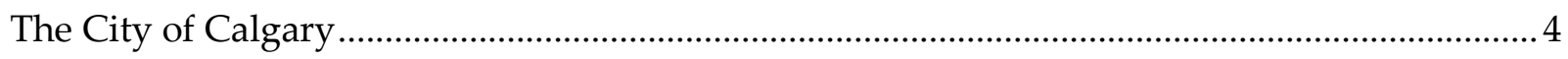

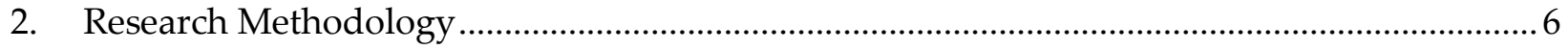

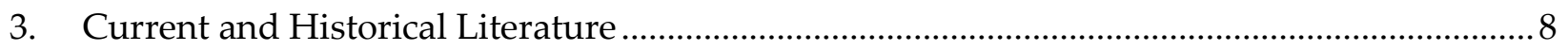

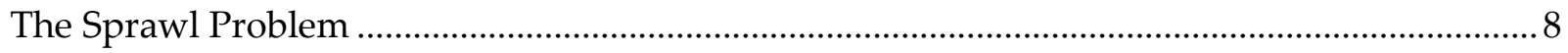

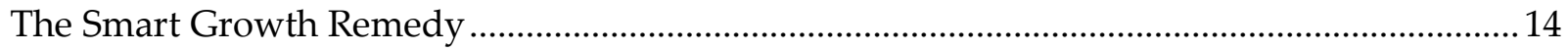

How did we get here? A historical review of urban sprawl in Calgary ..................................223

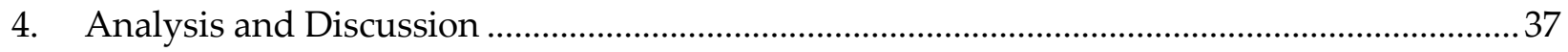

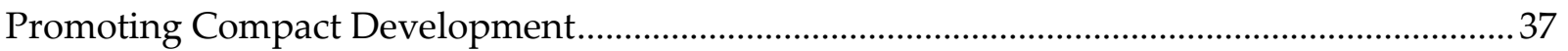

Providing and Promoting a Variety of Transportation Options ............................................... 48

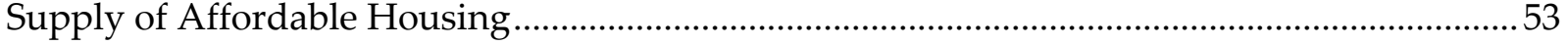

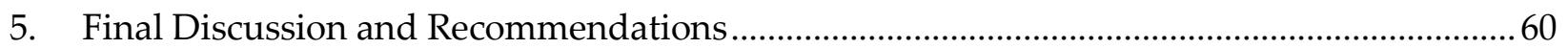

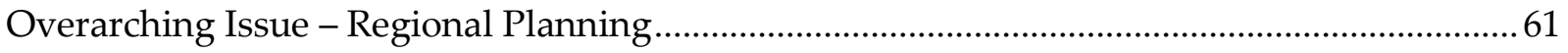

Promoting Compact Development.............................................................................................63

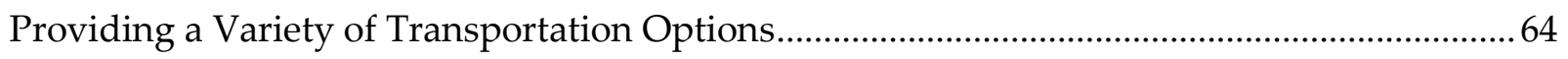

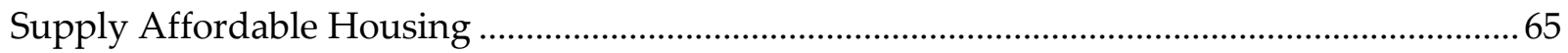

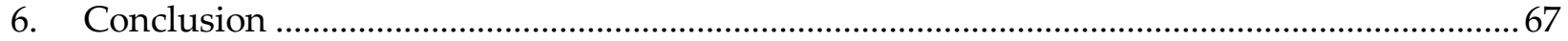

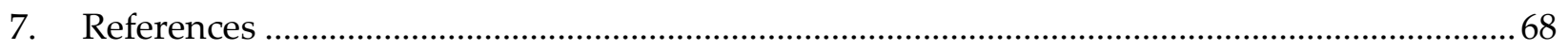




\section{List of Figures}

Figure 1: The Calgary Metropolitan Region (Calgary Regional Partnership, 2014)

Figure 2: Calgary's Spatial Growth from 1951-2012 (The City of Calgary: Geodemographics,

2014) .25

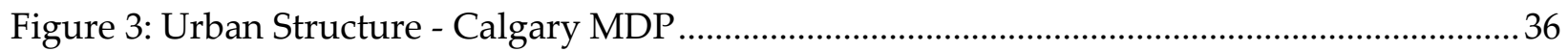

Figure 4: Calgary Population Change by Community (City of Calgary, 2013)............................. 40

Figure 5: Historical City-wide Population Density...... .43

Figure 6: Developed and Developing Areas Share of Population Growth from 1991-2014 (The

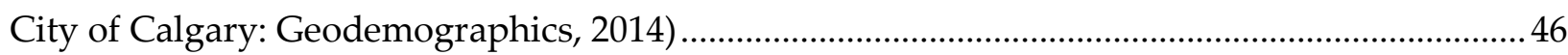

Figure 7: Geographical Distribution of Jobs (City of Calgary, 2011) ..............................................46

Figure 8: Investment in Transit Infrastructure since 2001 (Pembina Institute, 2014) ....................49

Figure 9: Calgary (Bus+LRT) Transit Ridership from 1996-2013 (American Public Transportation

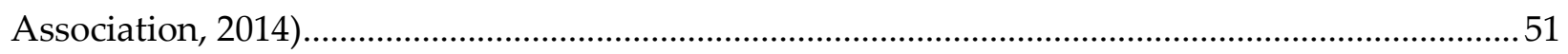

Figure 10: Mode Share in Calgary, 2005 and 2011 (City of Calgary, 2014) ...................................52

Figure 11: Cost Burdened Households from 1991-2011 (Statistics Canada, 2014) .........................57

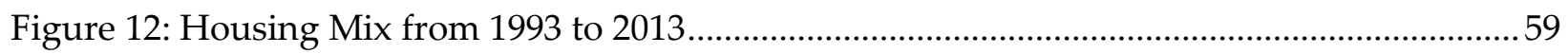

\section{List of Tables}

Table 1: Calgary Share of the Metropolitan Region (Statistics Canada, 2014)................................33

Table 2: Large Scale Intensification Projects in Calgary …........................................................... 41

Table 3: Historical Population Density from 1951-2011 (Statistics Canada)................................. 43

Table 4: Density 2011-2014 (The City of Calgary: Geodemographics, 2014) .................................44

Table 5: Population vs. Transit Ridership Growth (2009-2013) .....................................................51

Table 6: Median Value of Dwelling Relative to Income Growth (1991-2011) ...............................55

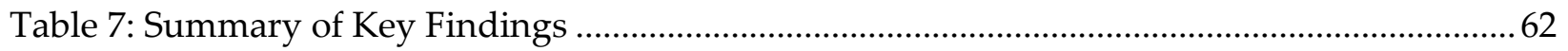




\section{Introduction}

Rapid urbanization in the form of sprawl has, and continues to be, a major problem facing municipalities. A dramatic shift occurred over the last 100 years as the population moved towards urban centres. At the turn of the 20th century cities accommodated approximately $15 \%$ of the global population. Presently, the number of city dwellers has drastically increased to account for about half of the global population (Neuman, 2005). The urban movement, specifically in North America, is characterized by a transition from more densely populated urban centres to sprawling suburban cities which rely, in some cases almost entirely, on the automobile.

The suburbanization of cities throughout this period has not occurred without problems such as traffic congestion and gridlock, increased pollution, loss of open space and agricultural land, increasing economic inequality and segregation, and health issues stemming from an altered suburban lifestyle. The underlying financial complications resulting from such problems are posing significant challenges, not just for municipal officials, but citizens. It appears that Canadian municipalities, specifically the City of Calgary, are at an important fork in the road. Does the city accept the status quo - growing in the same manner as it has for the last sixty years - or does the city adjust policy to reflect a more sustainable choice for growth?

Canada is a highly urbanized country. "Although it is estimated that approximately $80 \%$ of the Canadian population lives in an urban setting, the category includes downtown, inner-city, suburban, and exurban development. Initial estimates indicate perhaps that two-thirds of the Canadian population live in neighborhoods that most observers would consider suburban (i.e., 
cars and many postwar single-family homes)" (Gordon \& Janzen, 2013). As a poster child for suburban growth, Calgary has garnered a reputation based on a form of growth associated with urban sprawl; essentially, accommodating population growth at the city fringe through controlled low-density annexations. As the urban shift continues, growth in the suburbs is expected to remain. Opposition to urban sprawl has been mounting for several decades through formalized policies, plans and frameworks labeled as Smart Growth. These plans have only been recently introduced in Calgary and it is important that all stakeholders understand the implications to the City.

\section{Purpose}

The City of Calgary ratified a new Municipal Development Plan (MDP) in 2009 intending to guide and direct growth in the city over the next 60 years. In short, the plan is attempt to reign in Calgary's sprawling past utilizing Smart Growth, a term known to encompass the following principles (United States Environmental Protection Agency, 2015):

\section{Mix land uses}

2. Take advantage of compact building design

3. Create a range of housing opportunities and choices

4. Create walkable neighborhoods

5. Foster distinctive, attractive communities with a strong sense of place
6. Preserve open space, farmland, natural beauty, and critical environmental areas

7. Strengthen and direct development towards existing communities

8. Provide a variety of transportation choices

9. Make development decisions predictable, fair, and cost effective

10. Encourage community and stakeholder collaboration in development decisions 
Of the ten Smart Growth principles, Nelson (as cited in Blais, 2010), confirmed by Cervero (2001), highlight the two primary Smart Growth goals as: (1) building where infrastructure and development already exist by increasing density and (2) connecting land uses with transportation alternatives to the car. To narrow the scope of this paper, I will focus on the primary goals of Smart Growth as identified by Cervero and Nelson. In addition, the analysis will include a section on housing affordability because it is highly topical issue in Calgary at the moment.

The purpose of this study is to answer the question: Have select Smart Growth policies, embedded within the City of Calgary's MDP, been successful in battling sprawl and progressing towards the goals of Smart Growth? 


\section{The City of Calgary}

The City of Calgary is the largest municipality in the Province of Alberta, located in the Foothills of the Rocky Mountains at the intersection of the Bow and Elbow rivers. Calgary is surrounded by the City of Airdrie to the north, The City of Chestermere to the east, The Town of Okotoks to the south, and the Town of Cochrane to the west. In the last ten years, the combined populations of these municipalities have been increasing their relative share of the region. A map of Calgary and each of the surrounding municipalities is highlighted in Figure 1. One of the most rapidly growing municipalities in Canada, Statistics Canada (2015) identifies Calgary as the third largest municipality and the fifth largest metropolitan region in Canada by population. Totalling 1,195,194 people, Calgary is the dominant municipality in the region, containing $84 \%$ of the metropolitan population. From 1991-2011 the city grew by approximately $54 \%$ and has been experiencing significant population growth over the last five years, averaging about 3\% growth per year (The City of Calgary: Geodemographics, 2014). The city's economy is largely driven by the oil and gas sector which provides the majority of jobs, and one reason for above average incomes and relatively young population. The city is estimated to have the $11^{\text {th }}$ highest GDP per capita in the world, totalling $\$ 69,826$ (Brookings Institute, 2014), with a median age of 36, significantly lower than the national median age of 41 (Statistics Canada, 2015). 


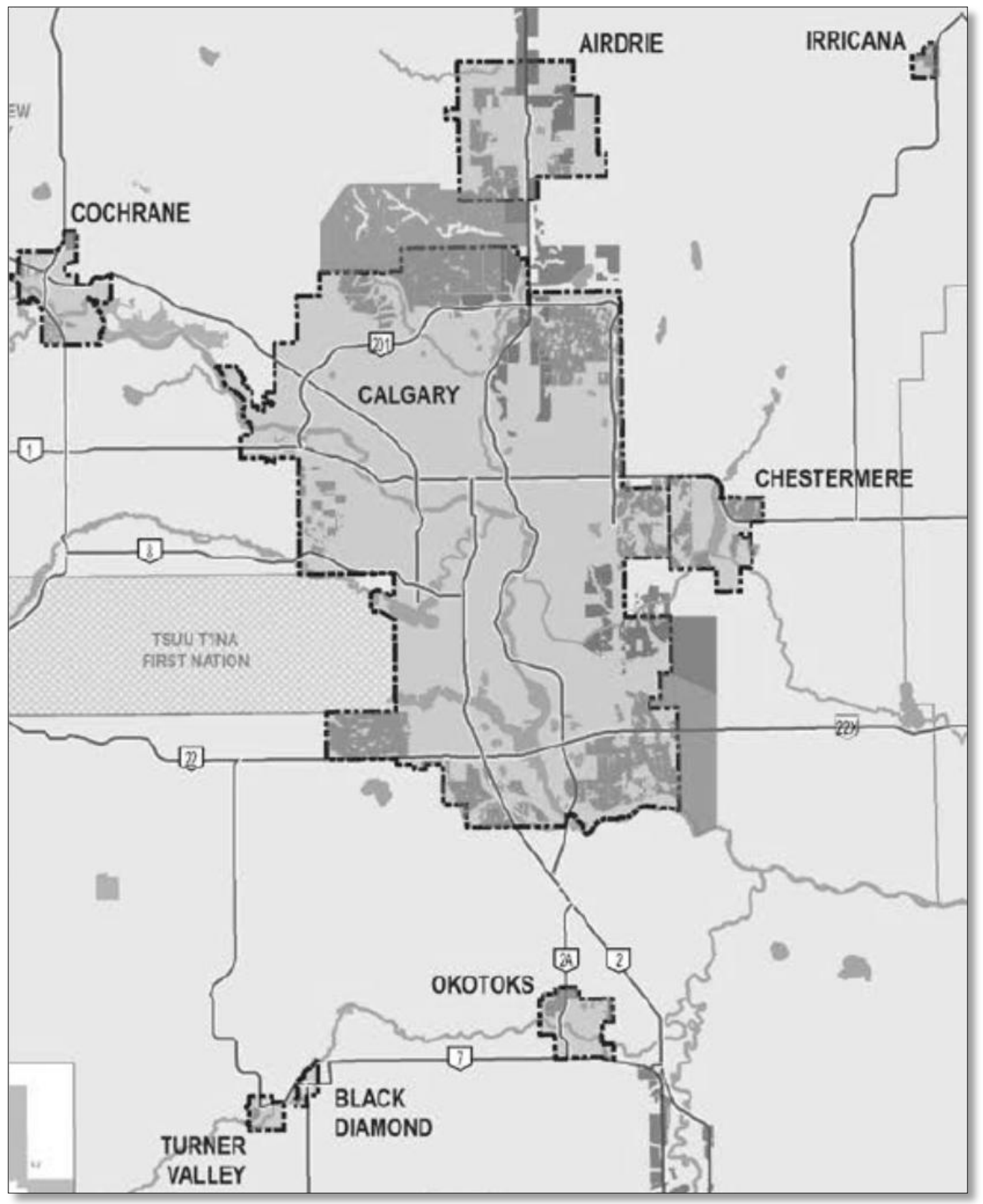

Figure 1: The Calgary Metropolitan Region (Calgary Regional Partnership, 2014) 


\section{Research Methodology}

The paper follows an applied case-study approach utilizing an evaluative model to discover if Calgary is meeting or progressing towards the primary goals of Smart Growth. The analysis considers how select goals of Smart Growth are considered in the city's statutory planning documents; primarily the Municipal Development Plan. The study encompasses three main components. First, a literature review on urban sprawl and Smart Growth is conducted to understand the urban sprawl, why it occurs, and to highlight problems pertaining to metropolitan regions experiencing this form of growth. This is a necessary step in order to understand arguments for and against sprawl and the social, economic, and environmental costs. Further, the literature on the history and application of Smart Growth in North America is reviewed to understand how policies have been incorporated into city planning documents and the overall result. This step is important to understand the goals of Smart Growth and the overall effect the goals and initiatives have on the practice of planning in general. The review is also used to identify some of the implementation barriers. The overall intent of the literature review is to extract key goals, indicators, and options to inform the analysis of Calgary.

Second, a historical review is utilized to understand the context of urban sprawl in Calgary in the post war period. Neuman (2006) argues that historical reviews can be a useful tool to show how a concept or issue evolved over time. Calgary experienced much of its population and economic growth during this period and it will be useful to understand the decisions made, the stakeholders involved, and some of the reasons which produced a sprawling urban form. 
Informed by the literature review, the final phase applies a set of indicators used in related studies to understand if the key goals of Smart Growth are being achieved in the Calgary context. In this section the key themes begin to develop which help inform a set of recommendations. 


\section{Current and Historical Literature}

\section{The Sprawl Problem}

The definition of sprawl itself is subjective and often debated as Blais (2010) notes it "could be viewed as an aesthetic judgement, as the cause of an externality (e.g. auto dependance), as the consequence of an action or condition (e.g. exclusionary zoning), as a pattern of development, or a process of development." One simple definiton is offered by Brueckner (2000) who identifies sprawl as the excessive spatial growth of cities over a specified geographical area. The word excessive is associated with commute times, agricultural land conversion, centre city decay, and public infrastructure costs.

The roots of sprawl are attributed to the post-war period of the early 1950s. The literature identifies the invention of the automobile and the federal housing programs as major contributors to the suburban era (Burchell et al, 2005; Blais, 2010). Subsidization of highway infrastructure and home ownership, fragmented governance, engineering standards, and consumer preference (real or perceived) are identified as major contributors which enhance sprawl (Blais, 2010). In general, research conducted by Ingram et al. (2009), found that income and population growth are significant drivers of urban sprawl and reduce overall development densities. This has been confirmed by Glaeser, Kahn, and Rappaport (2008) who found that when personal income doubles, lot size expands by about 25 to 50 percent. There are many drivers of sprawl, however, it may be best summed up by Bullard (2007, p. 1) who states "suburban sprawl is fueled by the 'iron triangle' of finance, land use planning, and transportation service delivery." 


\section{Characteristics}

Characteristics of urban sprawl include low density development, rigorously separated land uses (e.g. long distances between residential and commercial), leapfrog development, undeveloped gaps between land, and high dependency on the automobile. The most common theme of sprawling cities is development on agricultural land (Galster, 2001; Downs, 2005, Thompson, 2013). Perhaps one definition that best identifies the opposite end of the Smart Growth spectrum is "a pattern of land use that exhibits low levels of some combination of eight distinct dimensions: density, continuity, concentration, clustering, centrality, nuclearity, mixed uses, and proximity" (Galster, 2001). Canadian examples of sprawl exist in almost every city in varying forms. The largest cities have experienced significant population growth, however, the amount of new land that each acquired for growth has varied (Gordon \& Janzen, 2013).

\section{Costs of Sprawl}

Sprawl is associated with high economic, social, and environmental costs that counteract the goals of sustainability. There is no doubt that sprawl is devastating to the environment. Among the most serious problems is resource depletion due to urban land accumulation which occurs through a disproportionate consumption of agricultural and fragile environmental lands (Burchell, 2002). Lands located to the east of Calgary are stated to be prime agricultural lands. The agricultural productivity of these lands will be challenged if sprawl continues. Supplying residents with water, specifically in Calgary, is becoming ever more challenging as the city and its surrounding municipalities continue to urbanize. It is estimated that the amount of imperviousness created by converting agriculatural land or open space to low-density development amounts to billions of litres of water not being infililtrated every year (Blais, 2010). 
A major environmental cost associated with urban sprawl is increased automobile usage and travel trip distance. This leads to a greater consumption of fossil fuels, increased air pollution, water pollution, and soil erosion (Burchell, 2002; Frumkin, 2002; Blais, 2010). It is crucial to understand environmental factors because, as Campbell (1996) argues, they are prerequisites to achieving goals of social and economic sustainability.

Given our market-driven economy, issues are often legitimized when there is a realization that public and private financial costs are becoming excessive. The most complete studies on urban sprawl highlight that its costs are greater than those in Smart Growth scenarios (Burchell, 2000; Neuman, 2005; Blais, 2010). Scenario analysis has become an important aspect illustrating the problems with urban sprawl, specifically related to the financial costs of infrastructure and the annexation of agricultural land (Burchell, 2000). Multiple studies in both the American and Canadian context quantify the economic costs of sprawl. Burchell's (2002) research in particular, compiled data from multiple American states in an attempt to identify costs of compact versus a sprawling growth scenarios. The study found that the financial cost savings associated with compact development are approximately 420 billion dollars, with the majority stemming from reduced housing and development costs.

Overall, Burchell's research discovered that compact development typically results in cost savings of $25 \%$ on roads, $5 \%$ on schools and $20 \%$ on utilities (as cited in Blais, 2010). In the Canadian context and of particular interest to this paper, the City of Calgary found that by adopting a plan focused on densification that used 25\% less land, it could save approximately 11 billion dollars in capital costs and an additional 130 million dollars in operating costs 
throughout the life of the plan (IBI Group, 2009; Taylor et al., 2014). These costs are primarily focused on capital infrastructure projects related to water, sewers and road facilities.

Additional services, spread over a wider geographic area include schools, libraries, recreational facilities, garbage pick-up and mail delivery, can also increase financial costs. Maintenance and operational costs are also covered by the municipality indefinitely, which can lead to significant revenue shortfalls. "The City of Edmonton estimated that this shortfall will exceed $\$ 4$ billion dollars over the next 60 years" (Thompson, 2013). Further, Toronto found that savings on capital and operating costs for transportation and utilities range between 18 to 29 percent depending on the density of growth (Blais, 2010). The financial inefficiencies related to sprawling development create major problems for municipalities and are best summed up by Burchell et al. (2005, p. 74) who posits:

"[Municipal] attempts to collect enough revenue to provide services to residents, businesses, and workers fall short as they struggle to maintain aging infrastructure while also providing new roads, water, and sewer lines, and other forms of developmental infrastructure. The increased costs end up being passed along to businesses and residents through higher taxes and fees, and sometimes through fewer public services. Sprawl's fiscal impact may be a major reason local governments have become so interested in more efficient forms of development."

Much of the research focuses on the economic and environmental costs of sprawl, however, there are noted social impacts associated with sprawl such as decreased accessibility, social segregation, housing segregation, unequal property-tax funding of public schools, jobs-housing 
imbalance, the spatial imbalance of economic opportunity, and unequal access to open space and recreation (Neuman, 2005; Burchell et al. 2005; Blais, 2010). In addition, it is argued that a reliance on the automobile is creating a society that segregates more often than integrates, excluding invididuals from activities due to difficulty of access. This tends to affect individuals who are young, old, poorer, newly immigrated or disabled (Blais, 2010). More recent studies are linking sprawl to health issues such as mental health problems, increasing automobile deaths, obesity and diabetes (Frumkin, 2002; Thompson, 2013).

\section{Why sprawl?}

While researchers have identified many problems associated with sprawl, it has been one of the most dominant forms of urban growth over the last sixty years with some advocates identifying that sprawl has its benefits. One of the most commonly stated benefits is that it provides individuals and families with an ability to own a home that meets their desires. An American survey conducted in 1999 by Fannie Mae (a Government Sponsored Agency) found that, given the same cost, $83 \%$ would rather live in a large house in the suburbs rather than a compact one in the inner city (Burchell et all, 2002). This however, appears to be changing as Flint (2007) notes the demand for alternative options to conventional suburban built form are increasing. This trend has been confirmed by a study in Los Angeles conducted by Lewis and Baldassare (2010), indicating that support for compact development alternatives is significant and in some cases exceeds support for traditional, decentralized suburban patterns. Affordable housing options have long been the appeal of urban sprawl because individuals and families have followed the "drive until you qualify" motto (Flint, 2007). Yet, housing affordability associated with urban sprawl is becoming more scrutinized when costs such as travel are factored in (Flint, 
2007; Blais, 2010; Pembina Institute, 2015). Further, the relationship between housing

affordability and urban sprawl is considered far too simplistic as numerous factors contribute to housing prices. An American study by Nelson et al. (2002) found that market demand, not land use constraints, is the primary determinant of housing prices and that housing prices can increase under a sprawling or compact scenario. These results have been confirmed by Tomalty \& Haider (2008) in the Canadian context. There continues to be much debate regarding the benefits and costs, however, Blais (2010, p. 40) highlights a notable aspect stating "whereas the benefits of sprawl tend to be private in nature (e.g. larger lots and houses, freedom of automobile travel), the costs tend to be public (e.g. loss of farmland, higher infrastructure costs, greenhouse gas emissions, etc.)"

\section{Where do we go from here?}

A review of the literature suggests the problems associated with urban sprawl appear to outweigh the benefits. Urban sprawl is negatively affecting peoples lives and although the economic, social and environmental costs of sprawl are being realized, it is an assumption that Canadian cities will still continue to expand geographically. Gordon's (2013) research indicates that although the large Canadian metropolitan areas are seeing growth in city centres, the majority of growth is continuing in the suburbs (transit suburbs and automobile suburbs). A response to sprawl is occurring through policy, planning and design. The Smart Growth approach seeks to remedy the costs of sprawl, while accomodating increases in population expected by large Canadian municipalities in the coming years, particularly the City of Calgary. 


\section{The Smart Growth Remedy}

The formalized origin of Smart Growth is traced back to the mid-1990s and is currently understood as the antithesis to urban sprawl (Burchell et al., 2000, Burchell, 2002; Downs, 2005;

Dierwechter, 2008; Blais 2010). In its very basic form, it is a growth management planning response to the negative aspects of urban sprawl. The movement idealizes the economic, environmental, and social elements of sustainability to enable an alternative form of urban growth to that of conventional urban sprawl. Like sprawl itself, there are many definitions and interpretations of Smart Growth, yet, they generally comprise two primary elements. As mentioned in Section 1, Nelson (as cited in Blais, 2010) identifies these as: (1) building where infrastructure and development already exist, as opposed to greenfields, and (2) connecting land uses with transportation alternatives to the car. Distilling the definition into the primary elements makes the topic easy to digest and highlights that the key aspects of the Smart Growth initiative are to link transportation and land use planning while increasing density to support a more compact urban form. These primary features in addition to impacts on housing affordability will be the subject of analysis in this paper.

\section{The Origins of Smart Growth}

A major difference between Smart Growth and its growth management predecessors, including urban containment, is that its principles are built on more of a pro-growth base rather than the pro-conservation efforts of previous decades (Burchell, Listoken, \& Galley, 2000). This is one of the reasons that Smart Growth is more widely accepted by a variety of stakeholders including planners, developers, farmers, politicians, environmentalists and citizens. Burchell et al. (2000) 
states that Smart Growth is an initiative of the American Planning Association, The United States Department of Housing and Development (HUD), Henry M. Jackson Foundation, Natural Resources Defense Council (NRDC) and the Surface Transportation Policy Project (STPP). In Canada, Smart Growth first saw an organizational movement in 1999, through "Smart Growth BC," a non-profit started at the University of Victoria (Tomalty \& Curran, 2003).

The Smart Growth initiative calls for new plans and policy tools that enable a new form of development to compete with urban sprawl in the "policy forums and the marketplace" (Burchell et al., 2000, p. 825). The literature identifies the origins of Smart Growth as the third of four waves ${ }^{1}$ found within the evolution of growth management policy beginning in the 1950s (Degrove, 2005; Ingram et al., 2009; Chapin, 2012). The first being the era of growth controls focusing on limiting growth through boundaries and growth caps in order to advance environmental protections. This approach viewed growth as an impediment and seeked to control it through strict regulation. The second, titled the era of comprehensive planning, occurred from the 1970s to the 1990s and highlighted development as a problem which needed to be managed. This was done by preparing comprehensive, long term, planning documents which provided a vision, goals, indicators and rigourous analysis. Some of the best plans linked planning to economic development and the budgeting process. The comprehensive planning era transitioned to the Smart Growth era because, as Chapin (2012, p. 10) theorizes:

\footnotetext{
${ }^{1}$ The movement is originally conceptualized using the three-wave model developed by John Degrove. Timothy Chapin who argues the emergence of a fourth wave has recently expanded upon the model developed by Degrove.
} 
“Comprehensive plans sometimes simply reinforced the status quo, leading to inefficient or simply poor development patterns or the continued marginalization of traditionally ostracized groups. Comprehensive planning processes and the plans themselves became overly technical, bureaucratic documents that inhibited proactive, innovative planning. Development interests complained that these complex documents, with their often arcane rules and policies, lengthened already onerous development review times, drove up costs, and yielded few improvements in the built form or urban pattern."

The limitations of comprehensive planning introduced a third wave which Degrove (2005) calls the shift to Smart Growth. In this wave, development is viewed as a positive opportunity that needs to be embraced while attempting to control sprawl. Smart Growth is generating a greater degree of support than its predecessors because it identifies a need to consider market influences such as economic development, consumer demands and private interests. It is a collaborative approach that is enhanced through the use of incentives, disincentives and publicprivate partnerships rather than control. These elements are echoed by Goetz (2013) who observes that Smart Growth studies have identified tangible benefits associated with the adoption of Smart Growth plans and policies. Such claims are that, in battling sprawl, Smart Growth has developed a more consensus-based, collaborative approach which considers the growing "market demand for alternative urban activity centres and neighbourhoods different from the typical low-density suburban development model" (Goetz, 2013, p. 2191). 


\section{Smart Growth in Practice}

As American and Canadian municipalities began incorporating Smart Growth principles into plans at varying levels of governement (i.e. state, province, city-wide), the literature started highlighting its benefits. A firm argument that Smart Growth is a favourable policy tool in promoting an alternative urban form started to develop. These benefits, however, demonstrate various results depending on how they are implemented. Current literature exists in two forms: (1) qualitative case studies evaluating Smart Growth policy and offering recommendations and, more recently; (2) quantitative analyses of a large number of cases.

Studies on Smart Growth policy implementation are producing a variety of results, however, a trend is that the compact form associated with it, is not just a cheaper option in terms of financing infrastructure but also contributes to increased economic performance (Nelson and Peterman, 2000; Cervero, 2001). Cervero (2001) found that, all else being equal, cities that are compact and accessible by efficient transport infrastructure are among the most productive settlements. This is attributed to the basic theory that densely populated cities act as incubators and, when clustered together, supply firms with access to employment pools. Matched with efficient transportation networks, productivity increases by allowing individuals to spend less time commuting. Further, a study conducted by Nelson and Peterman, measuring economic performance of 192 municipalties with the presence or absence of growth management frameworks found that growth management policies focused on increased density are postitively associated with economic performance (Nelson \& Peterman, 2000). In the United States, a Smart Growth policy review conducted by Ingram et al. (2009) which compared four 
states with Smart Growth development approaches with four that did not, found those states with Smart Growth policy and plans experienced positive outcomes such as decreased loss of open space, lower levels of congestion, densification within the built-up area and increased transit use.

Goetz's study of Denver, Colorado (2013), a city comparable to that of Calgary, presents an example where Smart Growth policy has been embraced, while conventional urban development remains as the dominant form of urban growth. Similarly, Denver experienced rapid population growth in the 1990s. Urban sprawl was the dominant form of growth, resulting in the common problems of increased pollution, vehicle miles driven, and infrastructure funding issues. Due to this, the municipality embarked on a planning process resulting in a Metro Vision plan based on Smart Growth principles. Specific elements “included a voluntary urban growth boundary that was initially set not to exceed 700 square miles, a focus on higher-density development in designated urban centres, designation of four freestanding communities, improving air quality in the region and, most significantly, a rail transit system that would serve as the backbone of the regional transport system" (Goetz, 2013). Mayors of the Denver Metropolitan Region also formed a voluntary Metro Mayors Caucus (MMC), similar to the Calgary Regional Partnership (CRP), using a collaborative and consensus-based approach to assist in the development of a consistent and cohesive vision for the region. Goetz's study highlights that Smart Growth has been more successful at implementing a paradigm shift to conventional development. Challenges still exist, but Denver is noted to be changing its growth 
trajectory by increasing job and population densities, developing mixed-use nodes and increasing transit use.

\section{Addressing the Challenges}

Implementing Smart Growth principles does not come without challenges. As Downs states (2007, p. 369), "few regions have put into practice the most problematic principles. And almost no areas (not even Portland, Oregon) have implemented all of Smart Growth's principles." Downs' work identified the following eight obstacles to Smart Growth implementation. It is important to note, however, that these can occur whether the barrier is real or perceived.

- Redistribution of societal costs and benefits

- Lack of regional guidance

- "Nimbyism" regarding increased density

- Increasing home prices

- Increasing traffic congestion
- Increasing "red tape" associated with the approval of new developments

- Restricting profits (particularly for owners of outlying agricultural land)

- Public perception regarding centralized planning

The overarching barrier to achieving Smart Growth is that it results in a different set of benefits and costs for different groups. For example, individual land owners who intend to capture the value of their land on the outer ring of a municipality may be against Smart Growth. These individuals will likely reject associated policies because they will no longer be able to capture the value of that land while, under the smarter growth scenario, an individual owning land in the centre city may be better positioned to capture the land value. If policy contains some levels of uncertainty, Burchell (as cited in Downs, 2007) notes that individuals are hesitant to support 
it. The redistribution of said costs and benefits, and a level of uncertainty, produce a new set of advocates and opponents. Downs (2007, p. 369) illustrates this example simply by stating that "this is a serious difficulty associated with changing any fundamental arrangements in a complex society." This is probably the largest barrier to implement Smart Growth policy. If redistribution is to occur as a result of Smart Growth implementation, a regionalist strategy shifting power from municipalities to a higher level of decision making, may be essential (Downs, 2007). From this point, there are two options: Smart Growth principles can (1) be mandated (legislatively) or; (2) Jointly agreed upon through consensus.

Evidence of both cases exists in the Canadian context. In Ontario, the Growth Plan for the Greater Golden Horseshoe, legislated through the Places to Grow Act, illustrates a case where the Provincial Government mandates Smart Growth policy upon its "creature" municipalities in Southern Ontario (Ontario Ministry of Municipal Affairs and Housing, 2006). The policy requires that municipal level plans (i.e. Official Plans) conform to the provincial legislation. The overarching plan orders such planning principles as to where density should occur and which areas will be dedicated as employment (i.e. industrial) land. Provincial willingness to set planning goals, imposes them on municipalities, and monitor compliance provides a level of planning that is not currently occurring in Alberta. Nevertheless, Ontario provides an example of implementing Smart Growth policy through regulation.

Metropolitan Vancouver offers an example based on consensus. The municipality incrementally developed a collaborative system of regional planning over the past century. This is a long time horizon; however, research conducted by Taylor et al. (2014, p. 40) found that "a shared belief in 
urban containment and intensification is now deeply embedded in local political discourse and in the practices of planning professionals and the development-builder industry." One thing to note is that in the two examples of Toronto and Vancouver, an urban containment boundary is utilized (The Agricultural Land Reserve in Vancouver and the Greenbelt in Toronto). The geographical differences of each region need to be considered when analyzing the relative approaches to urban growth.

Calgary's use of the Framework for Growth and Change signifies, to some degree, a move to redirect population between developed and developing communities. It is also an attempt to phase the timing and location of growth and identify how it will be financed. Although not formalized through a geographical urban growth boundary (UGB) the framework attempts to focus growth in planned areas. Geographically imposed boundaries would make intensification easier, however, doing so in Calgary would be politically challenging. The challenge has been identified by Nelson and Dawkins (2004, p. 16) who identify that "containment requires a regional perspective in which some meaningful effort is made to direct development to specific areas and away from others where development would proceed in the absence of intervention."

\section{The Future of Smart Growth}

Although this paper is focused on Smart Growth, particularly at a local level, Chapin (2012) does explore interesting evidence suggests that growth management planning is entering a fourth era which he titles the sustainability era. He argues that planning will begin considering macro level issues such as energy diversification, climate change, economic development, employment and affordable housing. The distinctive characteristic of this era is that local and 
regional plans will be linked to national plans and policies. Further growth management, he argues, will ascend the regional levels (i.e. provincial plans).

Similar arguments are made by Ingram et al. (2009), based on their comprehensive study suggest that new rationales for Smart Growth are being realized because:

“States are expected to turn to land use planning to help achieve emission reduction goals; a new regulatory regime will benefit development proposals that adhere to Smart Growth framework; and market forces may also encourage more compact mixed-use development as households attempt to limit their travel costs and achieve other energy savings."

There is some evidence of this occurring in Canada. The most notable example is the aforementioned Growth Plan for the Greater Golden Horseshoe. There is also some evidence that this is occurring in Alberta. The recently introduced Alberta Land Use Framework and the associated South Saskatchewan Regional Plan, including Calgary, signal an increased presence in regional planning from the Alberta government.

The literature presents hopeful signs that Smart Growth principles are successfully encouraging an alternative to sprawl. While this section provides a broad synopsis of the Smart Growth literature, the analysis section will incorporate additional research relating specifically to the element being discussed. 


\section{How did we get here? A historical review of urban sprawl in Calgary}

"The past invariably shapes the present and partly determines the contours of the future, for societies cannot - and do not-break from the past so much as work with it to create a 'usable future.'" (Brooks as cited in Dierwechter, 2008, p. 16)

\section{Motivations for Sprawl}

We cannot look at the rise of Smart Growth policy in Calgary without understanding how the City arrived at this point. The usefulness of a historical review is best summarized by Burchell et al. (2000, p. 838) who states: "the luxury of looking back 50 years is that we know how things turned out." As mentioned, Smart Growth policy emerged from the economic, social, and environmental costs related to urban sprawl, many of which Calgary is only recently beginning to understand. One of the key reasons urban sprawl is the dominant form of growth in Calgary is because much of the rapid population increases it experienced occurred during the rise of the automobile in North America. This enabled individuals to live further from their jobs and social activities. Calgary is not considered to be bound by its geography in ways similar to Vancouver or Toronto. Even today, Calgary's sprawling form, based on aggressive outward expansion still accounts for only $10 \%$ of the CMA while $90 \%$ is farmland (Tomalty \& Alexander, 2005).

Therefore, Calgary's ability to grow outwards, through land annexations, was a popular motive of developers during the post-war period as they "established a notion that outward growth was cheaper and therefore better than operating within the existing boundaries" (Foran, 2009, p. 42).

One of the unique features highlighted in the literature is that The City subscribed to a to a "UniCity" model that enabled one level of public authority to govern the population (Tomalty 
\& Alexander, 2005; Ghitter, 2008; Foran, 2009; Taylor et al., 2014). The model is noted to have been adopted as early as 1955 and primarily focused on annexing fringe cities and villages with a regional justification based on financial efficiency and planning control. The model was formalized, as Taylor highlights, in 1956 when the McNally commission confirmed and enabled an official policy, later known as the UniCity principle (Taylor et al., 2014). The model is still prevalent today; however, it is showing signs of being challenged. The satellite municipalities of Airdrie, Chestermere, Okotoks, and Cochrane have established large enough populations to enhance their level of independence in the region. Figure 2 depicts Calgary's UniCity expansion from 1951 to 2012 in relation to the city's current municipal boundary. 
Calgary's spatial growth, built form and municipal limits, 1951- 2012
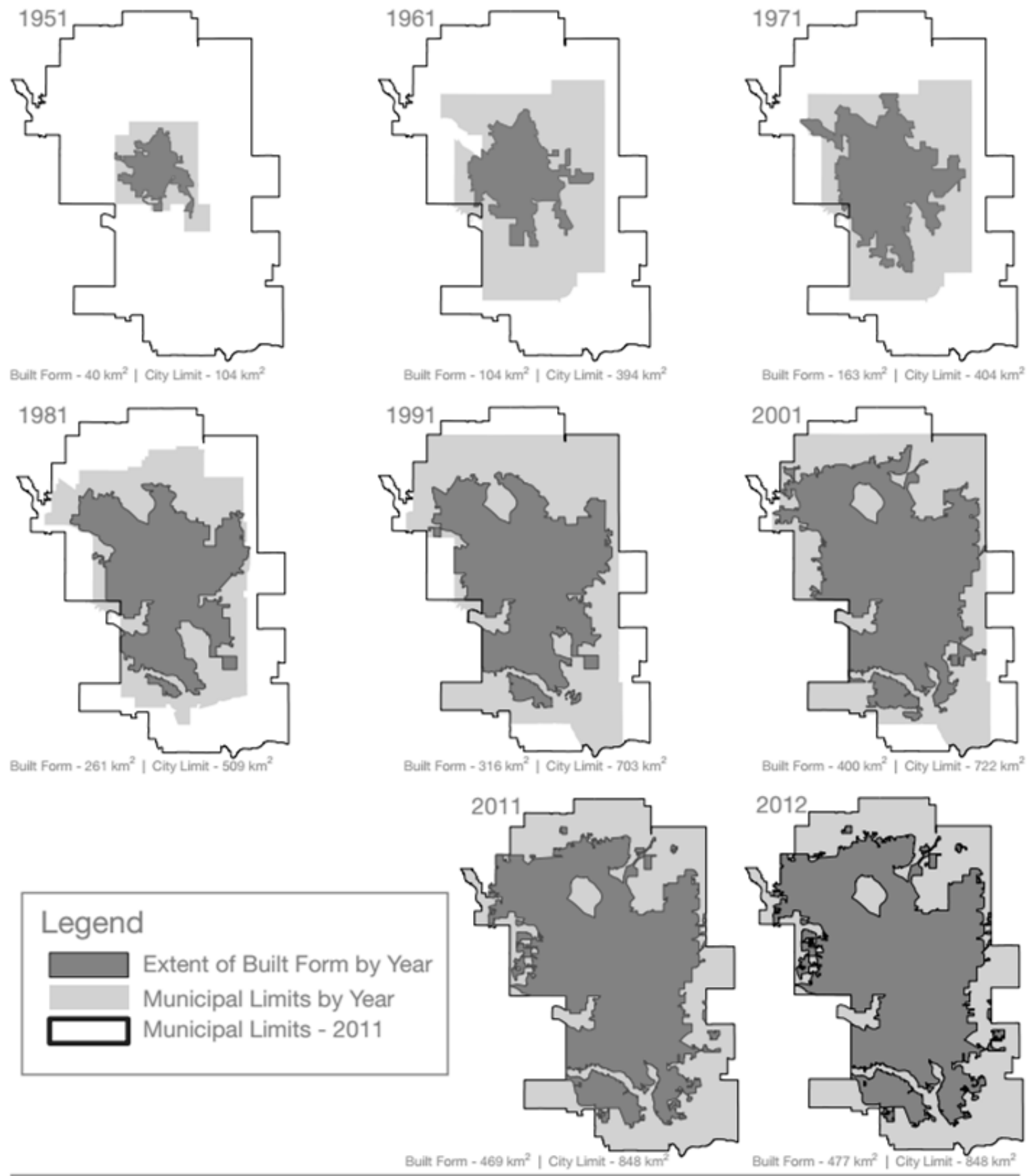

[56] CALGARY SNAPSHOTS

calgary.ca/geodemographics

Figure 2: Calgary's Spatial Growth from 1951-2012 (The City of Calgary: Geodemographics, 2014) 


\section{Early Days: 1945-1962}

The foundations of urban sprawl, Foran (2009) argues, were laid during the period of 1945-1962 in which trends formed patterns of development that were replicated over multiple decades. By 1955 these values were firmly entrenched in the mindset of city officials, developers and citizens alike. During the period of 1956 to 1961, Calgary annexed large quantities of land, growing its boundaries from 40 to 151 square miles. Street car lines were removed to make way for highways and private developers were given the opportunity to build and finance their own subdivisions. The City also exited land development entirely in 1958 with its sale of 182 acres of land to private interests. In this period, Calgary began its momentous shift to a suburban form, identified as "the age of the developer" (Foran, 2009, p. 23).

The majority of new developments were low density, automobile-oriented communities which reinforced modernist city planning principles apparent during this time period. Zoning practices also reinforced low density built form (e.g. single family homes), while city officials declined to increase densities; a move that was supported by developers who preferred single family home construction. This form of housing became the norm while developers and city staff "generally assumed that all buyers wanted it" (Foran, 2009, p. 73). Out of the 43,000 housing units built during this period, approximately 37,000 were single family homes. Condominium construction was so miniscule that is was not even reflected in building statistics until 1975 (Foran, 2009). The lack of diverse housing options provided during this era can be identified as catalyst that accelerated urban sprawl because it reduced choice and created a standard expectation. For example, when the community of Thorncliffe Heights was being construction, the developer was able to secure a caveat that the entire area would maintain R1 
zoning (i.e. single family homes) for 15 years (Foran, 2009). The result is that neighbourhoods such as this currently experience some of lowest densities in the city and, although relatively close to the city centre, are only recently showing signs of intensifying.

\section{The 1970s: Hints of Smart Growth}

Developer stance against growth control measures in the 1970s was based on the same underlying argument today - that rising house prices are linked to the shortage of available land (Foran, 2009). Under the UniCity model, Calgary continued to grow through annexations with the aim to control growth in fringe communities located outside the city limits and enable orderly expansion of planned development. In 1977 the City of Calgary introduced the Balanced Growth Policy which was a long term strategy for accommodating the large expected population increases. The plan evolved out of eight alternate growth approaches for the City, of which only three proposed an increase in density. Of the eight, two would be considered "Smart Growth" strategies in the present time period and are summarized below:

- Strategy A: The Compact City - Annexation was discouraged and densities are increased. The City would accommodate half of the population increase within the built up area and the other half through suburban expansion (the exact same goal is contained within the present day MDP). The use of the car was discouraged and the majority of the plan was based around public transit.

- $\quad$ Strategy D: Maximum Efficiency of Investment and Resources - This plan attempted to increase densities within areas where infrastructure was present, primarily on 
transportation routes. Six nodes were established with about half of the population increases contained within the central area.

These two options present particularly interesting pieces of information because they detail an understanding of Smart Growth policy almost 30 years before the major policy shift occurred in Calgary. Strategy A includes the same principle for accommodating population growth as the current MDP. The 50/50 split for accommodating population increases is the current goal for 2076.

Although these strategies were favoured by city officials and the corresponding business units, they were rejected by Council. Foran suggests that The City likely bowed to the pressure from developers and approved a strategy favouring outward, low density growth. He goes on to state: "It was in many ways a historic policy decision, and was likely the City's last opportunity to curtail a 25 year trend and marked a victory for the land developers" (Foran, 2009, p. 121). This presents a discouraging reality that illustrates the barriers to intensification and the grueling long-term process to increase density.

Even pragmatic approaches, justified on market principles, were rejected during this period. For example, Foran (2009) notes that, one developer proposed to build a high density, affordable apartment in the city centre. The project aligned with the City's General Plan at the time to accommodate density increases within transportation corridors. A required zoning amendment, however, was rejected multiple times on the grounds that "the need for cheaper accommodation cannot be used as a criterion for rezoning and that any rezoning at this time would be a breach of faith with those developers who have constructed duplexes" (Foran, 2009, 
p. 190). Further, another apartment development in Sunalta was rejected on the grounds that high density development should not be mixed with single family and low density developments (Foran, 2009). One of the large city developers attempted to experiment with mixed-use, higher densities and a town centre concept as early as the 1960s (early New Urbanism). The town centre concept was not welcome and The City staff demonstrated very little support for it because they worried about traffic increases and according to Foran, it was (2009, p. 167 ) rejected on obscure grounds such as that "people would drive rather than walk to the shopping centre because their purchases would be too heavy to carry." Developer amenities also became popular during this period in the form of lakes, golf courses significantly enhancing the geographic size of communities.

Transportation planning also contributed to urban sprawl as streets were designed to "move traffic rather and emphatically not to accommodate business" (Foran, 2009, p. 177). This directly contrasts with how streets are viewed today, particularly within centralized neighbourhoods such as the Beltline, Mission, and Kensington. From this point, planning catalyzed the move to large shopping complexes, controlling entrance and egress, and the provision of off-street surface parking lots. I can empathize as to why these decisions were made; specifically to accommodate a major trend of increased car usage, however, looking back these decisions negatively impacted the city. I agree with Foran, that as a result of these decisions, the sprawling form was exacerbated. Examples such as these strongly contribute to the perception of Calgary as one focused on the automobile, single family homes and single use zoning. 
Most of the historical plans focus on outward growth as the norm rather than intensification, the preservation of affordable housing options and efficient use of existing infrastructure (Taylor, Burchfield, \& Kramer, 2014). There have been anecdotal mentions of mixed-use, increased density, transit oriented developments, and efficient forms of growth, yet they were typically rejected by the masses. As early as 1970, municipal planners identified a growing need to incorporate mixed uses and increase densities city-wide, however, Foran (2009) indicates that developers dominated planning and development in Calgary. Regarding the environment, Foran (2009) notes that Calgary sprawled across the open land, built on chernozemic black soil, which he states is some of the best in the world, however, at the time no one understood the implications or seemed to care. These insights were largely ignored as Calgary continued its outward growth pattern, relatively unchanged until the turn of the century.

\section{Historical Stakeholders}

Foran notes five influences contributing to sprawl in Calgary. They are (not in order of rank): (1) The City of Calgary, (2) Land Developers, (3) Home Buyers, (4) The Provincial Government, and (5) Canada Mortgage and Housing Corporation (CMHC) (Foran, 2009). City officials and developers were considered to be the main actors while demand for single family homes, made possible by the CMHC, perpetuated sprawl. During this period CMHC was actively involved and its "ubiquitous presence at planning stages meant that negotiations affecting housing were not exclusive to the City [of Calgary] and the developers"' (Foran, 2009, p. 14). As we will see, these forces still heavily influence development in Calgary today and will likely be the same in the foreseeable future. The parallels to the current developer mindset in the city today are astounding. During this time, increases in density were generally refused on the grounds of 
"property devaluation," "breaches of faith," and "regressive neighbourhood character," while parking requirements were introduced that further utilized vacant land (Foran, 2009).

\section{Recent History: Sprawl as a Regional Issue}

An important occurrence, seen as hindrance to reign in urban sprawl, arose in the 1995 when the Provincial Government replaced formalized Regional Planning Commissions (RPCs), with a voluntary mechanism for inter-municipal cooperation. Traditionally, RPCs gave Calgary indirect control over the pattern of urban development beyond its boundaries, however, the movement to voluntary regional planning, as Taylor et al. (2014) argues, is not as effective. The voluntary system is still in place today and is becoming a prevalent and controversial issue as the Calgary Metropolitan Region continues to become increasingly fragmented. Tomalty and Alexander (2005) also highlight the weak substantive wording of the MGA, stating that 44 of the 49 policies use "municipalities are encouraged." The lack of Provincial direction regarding regional issues has been voiced by municipalities including Calgary. For these reasons, the MGA is currently being reviewed and, while in the consultation process, stakeholders highlight that "municipalities cannot be mandated to collaborate; collaboration needs to be voluntary. However, the Province should encourage, facilitate, and incentivize regional collaboration" (Alberta Government, 2015).

In a continuing effort to control suburban growth, Calgary has refused to extend water trunk pipes to surrounding municipalities that do not meet minimum density targets, resulting in rural communities (e.g. Rocky View County) boycotting the CRP and its associated plan (Taylor et al., 2014). Nonetheless, surrounding municipalities with water capacity are continuing to 
grow rapidly. As a result, Calgary is beginning to reflect more of a metropolitan city form, ubiquitous in other large Canadian cities as its share of the regional population has been slowly declining since 1951 while "the regional population outside the City of Calgary has almost tripled since 1991, from 67,000 to 180,000" (Taylor et al., 2014, p. 9). More recent data indicates that the satellite communities are growing at a faster rate (as a percentage) than Calgary, decreasing the city's share of the regional total. The implication to planning highlighted in Table 1 is that, for the first time in history, satellite municipalities are growing more rapidly than the City of Calgary. Tomalty and Alexander (2005, p. 77) argue that:

"Given the high level of growth in the region, the continued provincial spending on highway upgrades, and the lack of regional governance institutions, exurban development outside the City of Calgary's boundaries is likely to become a more salient issue in the future. This development also undermines Smart Growth objectives within Calgary as it is frequently argued by those advocating a more laissez-faire approach to planning that managing growth with strong regulatory instruments will only push residents in search of low-density, segregated and homogenous communities into the exurban regions, an outcome worse than sprawling development within the city limits."

Recent population increases within exurban areas, as illustrated in Table 1: Calgary Share of the Metropolitan Region (Statistics Canada, 2014) support Tomalty and Alexander's viewpoint. Only recently has the provincial government become more involved in planning through the Alberta Land Stewardship Act passed in 2009. The South Saskatchewan Regional Plan, approved in 2014, impacts Calgary, requiring municipal plans to be consistent with the 
provincial document (Alberta Government, 2014). Regional planning as currently structured is still a problem because, as Taylor et al. argue (2014), the Act provides no mechanism for the province to assess, let alone enforce, municipal compliance, so the degree to which the policies influence local planning is not known. The MGA is currently under review, in the consultation phase, and the Province expects to finalize a new Act in 2016. A report detailing current consultations highlights that municipalities have encouraged the Province to become more involved in growth management and that the largest cities should have autonomy to decide various legislative and financial decisions and mechanisms (Alberta Government, 2015).

At present, Smart Growth buy-in remains as a significant challenge for Calgary and the CMA. As summarized by Taylor et al. (2014, p. 40):

\begin{abstract}
"Strident opposition by a powerful and well organized development industry that has no incentive to depart from a highly profitable suburban model is coupled with weakly institutionalized regional coordination and inconsistent political support on city council for the new planning direction. If this condition persists, Calgary may find it difficult to reorient its urban development policy regime from one premised on expansion and efficiency objectives to one oriented around intensification and sustainability objectives."
\end{abstract}

\begin{tabular}{ccccc} 
& $\mathbf{2 0 1 1}$ & $\mathbf{2 0 1 2}$ & $\mathbf{2 0 1 3}$ & $\mathbf{2 0 1 4}$ \\
\hline $\begin{array}{c}\text { Population } \\
\text { (City of Calgary) }\end{array}$ & $1,096,833$ & $1,120,225$ & $1,156,686$ & $1,195,194$ \\
$\begin{array}{c}\text { Population } \\
\text { (Calgary Metropolitan Area) }\end{array}$ & $1,264,500$ & $1,307,600$ & $1,357,600$ & $1,406,700$ \\
$\begin{array}{c}\text { Calgary Population } \\
\text { (\% Share of Regional Population) }\end{array}$ & $87 \%$ & $86 \%$ & $85 \%$ & $84 \%$ \\
\hline
\end{tabular}




\section{A Shifting Paradigm - The Municipal Development Plan}

At the turn of the century Calgary began to plan for increased densities and intensification.

When Calgary is compared to other major centres in North America, the city could be considered a Smart Growth laggard, although, processes that eventually crafted the MDP began in the early 2000s (Burchell, 2000; Taylor, Burchfield, \& Kramer, 2014). The development of Calgary's MDP, although led by city hall, included a significant portion of engagement with citizens. Downs highlights three groups that tend to be strong advocates for Smart Growth. They are: (1) nongovernment environmentalists; (2) urban planners and other local public officials and (3) innovative real estate developers. He goes on to argue that the commonality between these groups, in their promotion of Smart Growth principles, is that they do not include everyday citizens. In Calgary's case, the main group advocating for smarter urban growth options in Calgary are the local planners and public officials. The citizens in Calgary's case, however, proved to be identifying a need for growth patterns to change when they were consulted through a comprehensive engagement process to establish the city's 100-year vision, titled imagineCALGARY in 2005. At the time, imagineCALGARY was considered to be the largest visioning exercise of its kind, engaging over 18,000 citizens (City of Calgary, 2007). This initiated the Plan It Calgary process which eventually led to the Municipal Development Plan and Calgary Transportation Plan in 2009. This is a contrast to Downs's argument because, although mostly suburban, citizens advocated for a need to reassess the City's urban growth trajectory. 
The basis of Calgary's Municipal Development Plan is rooted in the Sustainability Principles for Land Use and Mobility adopted by Council in January 2007. These principles are heavily influenced by Smart Growth principles derived from both Canadian and American Smart Growth networks (City of Calgary, 2007).

The MDP divides Calgary's urban structure into six distinct geographic areas. These include Centre City, Activity Centres, Corridors, Developed Area Residential, Developing Area Residential and Industrial. These are highlighted in Figure 3: Urban Structure - Calgary MDP. The MDP includes 6 broad areas which include policies focused on:
1) A Prosperous Economy;
4) Urban Design;
2) Shaping a More Compact Urban
5) Connecting the City and; Form;
3) Creating Great Communities;
6) Greening the City.

\section{Key takeaways from the historical review:}

- Long history of sprawl engrained within the cultural mindset of Calgary's citizens, developers, and Council members

- Lack of regional guidance stemming from 1995 abolishment of formalized RPCs

- Excessive growth in suburban communities such as Airdrie, Cochrane, and Chestermere have the potential to undermine Smart Growth initiatives in Calgary

- Lack of regional planning authority to encourage and direct Smart Growth in the Calgary Metropolitan Region 


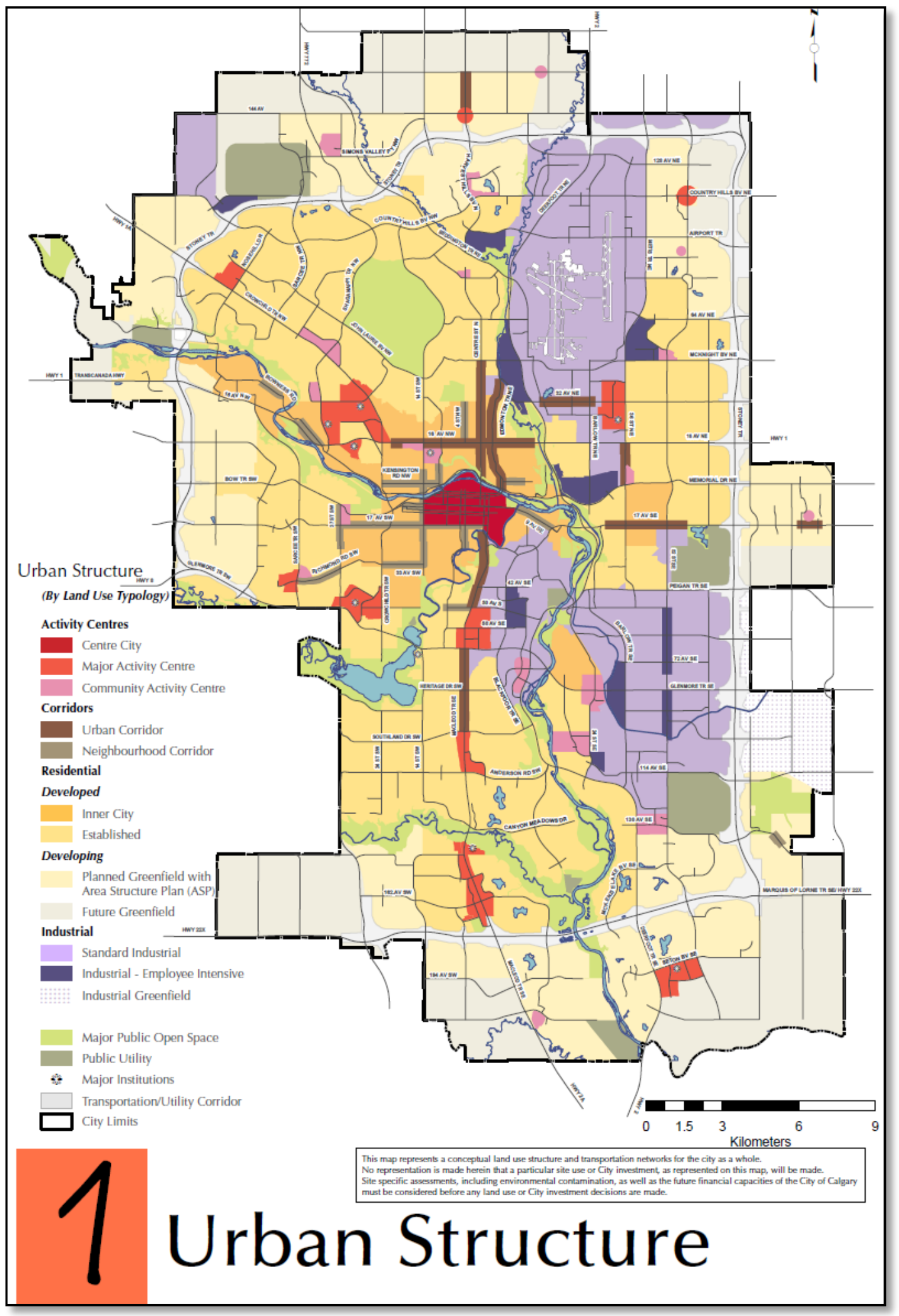

Figure 3: Urban Structure - Calgary MDP 


\section{Analysis and Discussion}

The structure of the analysis is based on the two primary goals of smart growth as identified in the literature (Cervero, 2001; Nelson as cited in Blais, 2010). As mentioned, this paper will additionally analyse the impacts of Smart Growth policy on housing affordability. Although not a primary goal of Smart Growth, it is one that is highly topical in Calgary, garnering significant public attention and often used as an argument against smart growth. These components, outlined below, will be used to organize the analysis in order to determine if MDP policies are progressing towards the overall goals of Smart Growth.

1) Promoting Compact Development - Building where infrastructure and development already exist by increasing density.

2) Providing and Promoting a Variety of Transportation Options - connecting land uses with transportation alternatives to the car.

3) Supply Affordable Housing - enhancing affordability and increasing options.

Key themes and takeaways will be presented at the end of each section and expanded upon in section 5 of this report.

\section{Promoting Compact Development}

This section examines growth and density trends in Calgary using Statistics Canada census data as well as that supplied in City of Calgary planning documents and reports. Section 2.2 of the Calgary MDP (2009), “Shaping a More Compact Urban Form,” identifies a need to direct growth in a way that efficiently uses current and future infrastructure. One of the policy options is to encourage increases in density, which Pamela Blais defines as "the single most important determinant of the efficiency of the use of land and infrastructure" $(2010$, p. 60). This is an 
important aspect because, as she explains, density plays such an important role in achieving the additional goals of Smart Growth and is a prerequisite that enables infrastructure such as higher order transit. One thing to highlight is the strong policy wording within the MDP regarding density. For example one policy reads "ASPs for new communities in Future Greenfield Areas will achieve a minimum intensity threshold of 60 people and jobs per gross developable hectare. This community intensity level includes NACs, CACs, Urban Corridors and Neighbourhood Corridors, as identified in the ASP. ASPs must also demonstrate how a target density of 70 people and jobs per gross developable hectare can be achieved over the life of the plan" (The City of Calgary, 2009).

Density and intensity are some of the more referenced terms in the MDP and are utilized in multiple measures including:

- Achieve a balance of growth between developed and developing communities by accommodating $50 \%$ of the population in each area by 2076 .

- Achieve a city-wide density of 27 people per hectare and 18 jobs per hectare by 2076 with high density accommodated in the city centre, urban corridors, and major activity centres.

- Achieve an intensity of 60 (demonstrate potential for 70) people and jobs per gross developable hectare in developing neighbourhoods and a minimum density of 20 units per gross developable hectare.

The following analyses seek to understand if Calgary has been densifying and whether or not the city is progressing towards a more compact model for urban growth. 


\section{Urban Form - Where is growth occurring?}

Before we examine density, it is important to understand the urban form of Calgary and how population growth is being accommodated. The majority of growth has occurred at the fringe, indicating that the city is having trouble accommodating population increases in the built-up area. Growth figures in the city centre (e.g. the Beltline neighbourhood) are promising; however, the outer suburbs are still the focal point of population growth. A map of population growth by community from 2001 to 2011 is highlighted in Figure 4; depicting high growth areas in yellow. Blue and grey show areas experiencing negative and stagnant growth respectively. The results demonstrate that the population is increasing mainly on the outer edge of the city, while the inner suburbs are seeing zero or negative growth. An inference from this is that policies supporting intensification have had a minimal effect on the inner suburbs, such as infilling or brownfield redevelopment. As of 2012,96\% of the population increases have been accommodated through greenfield expansion. While the centre city, central city, activity centres, and corridors typologies are showing signs of densifying, the established areas are declining in population. Another explanation, based on analysis conducted by Taylor et al. (2014) highlights that neighbourhood intensification in the developed areas area has not resulted in population increases because of declining occupancy rates.

Although the majority of the population increases are being accommodated in suburban neighbourhoods Taylor et al.'s (2014) analysis demonstrates encouraging signs that new suburban developments are consuming less land. Their research notes that suburban consumption was 2 hectares per 100 new residents in 2001-2011 versus $6.5 \mathrm{~h}$ in 1991-2001. 


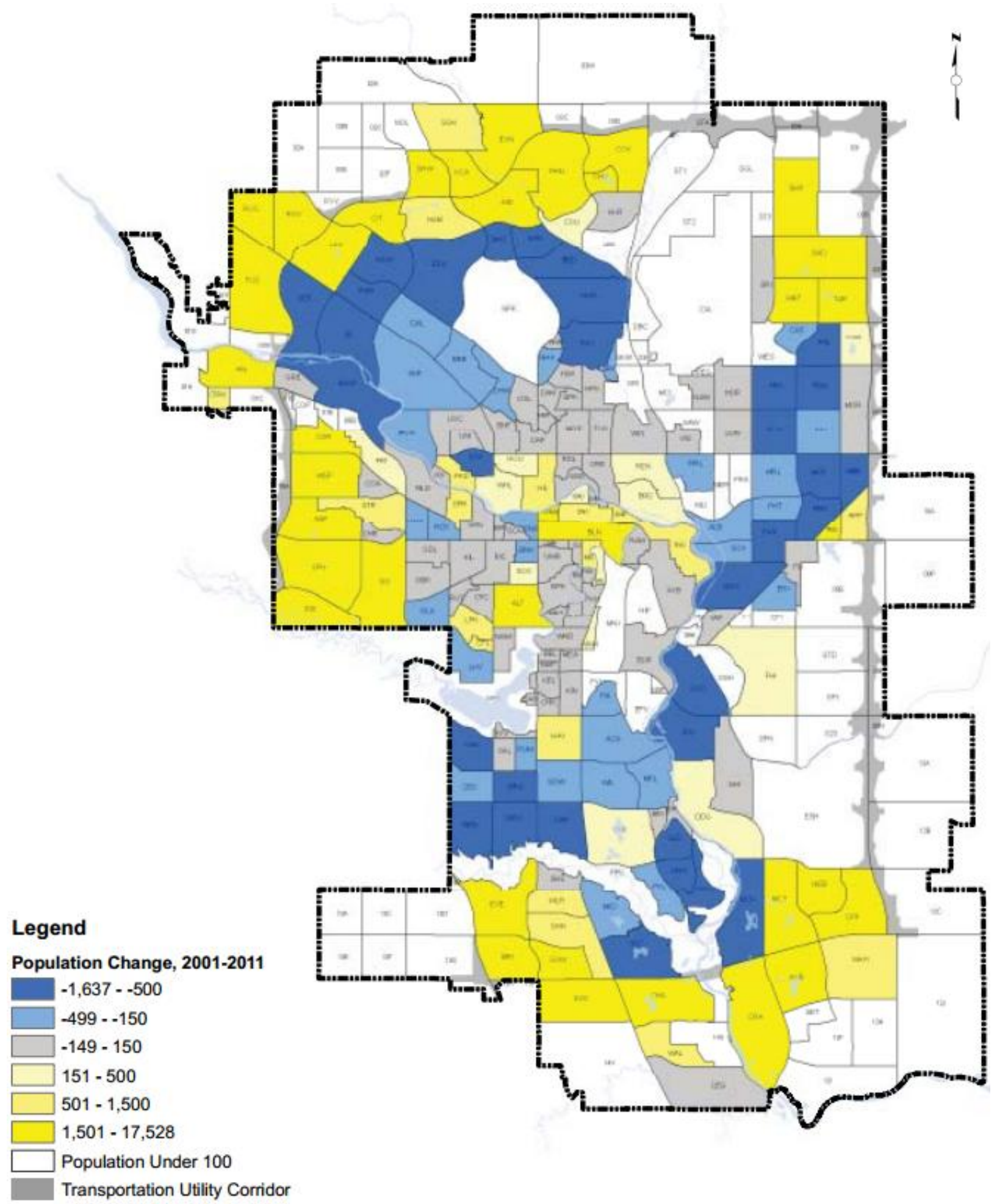

Figure 4: Calgary Population Change by Community (City of Calgary, 2013) 
Given the minimal impact intensification has had on increasing the population in the built up area, there are currently a number of large scale projects that have the potential to accommodate significant population within the built-up area. Two of these projects, East Village and Currie Barracks, are currently under construction. The final portion of the Currie Barracks plan is in the process of being amended to increase density (including the commercial hub) and is slated for approval in 2015. Each project is highlighted in Table 2: Large Scale Intensification Projects in Calgary, demonstrating high density and a potential to support large population increases.

\begin{tabular}{lccc}
\hline Project & Land Use Typology & $\begin{array}{c}\text { Population Forecast } \\
\text { (Total individuals based on } \\
\text { minimum and maximum scenarios) }\end{array}$ & $\begin{array}{c}\text { Density Forecast } \\
\text { (units per gross developable } \\
\text { hectare [upgdh) based on } \\
\text { minimum and maximum } \\
\text { scenarios) }\end{array}$ \\
\hline Currie Barracks & Inner City & 11,100 to 21,300 & $22-62$ \\
East Village & City Centre & 11,500 & (proposed) \\
\hline
\end{tabular}

Table 2: Large Scale Intensification Projects in Calgary

\section{Population Density}

Statistics Canada measures population density by the number of individuals per square kilometre using the municipal boundary. Measuring density using this approach can be deceiving because it includes large portions of undeveloped land. The MDP measures density on a per hectare basis using the built up area as the boundary. The built up area more accurately represents where individuals live and is more useful than calculating density based on the municipal boundary because it precludes greenfield land that is yet to be developed but exists within the municipal boundary. Density per kilometre and density per hectare based on built up areas are included in Table 3. 
As mentioned, the MDP focuses on increasing densities and promoting a compact urban form. Table 3 demonstrates Calgary's decreasing population density from 1951-2011. While the city experienced significant population and geographical growth over the 60 year period, population density decreased by $28 \%$. An inference is that any initiatives or incentives to increase population through intensification, specifically from 1951 to 2001, have been essentially non-existent. As described in the historical review, low-density policy was firmly rooted in the politics and culture of the city until the turn of the century. The observations noted by Foran are supported by the data presented in Table 3. Another explanation for decreased density this is the long term decline of average household size due to factors such as "including longer lifespans, delayed family formation, divorce, and family planning" (Taylor et al., 2014). An implication of this is that more housing is required to accommodate the same population and more housing requires more space. The only period in which density increased is the years between 2001 and 2011, growing by 6\%. The increase is consistent with the ideology shift to smart growth ultimately formalized by the MDP in 2009. 


\begin{tabular}{cccccccccc}
\hline & $\mathbf{1 9 5 1}$ & $\mathbf{1 9 6 1}$ & $\mathbf{1 9 7 1}$ & $\mathbf{1 9 8 1}$ & $\mathbf{1 9 9 1}$ & $\mathbf{2 0 0 1}$ & $\mathbf{2 0 1 1}$ & $\begin{array}{c}\text { Growth (\%) } \\
(\mathbf{1 9 5 1 - 2 0 1 1 )}\end{array}$ \\
\hline $\begin{array}{c}\text { Built-up Area } \\
\begin{array}{c}\mathbf{( k m}^{2} \text { ) } \\
\text { Built-up Area }\end{array}\end{array}$ & 40 & 104 & 163 & 261 & 316 & 400 & 469 & $1073 \%$ \\
$\begin{array}{c}\text { (Ha) } \\
\text { Population }\end{array}$ & 129,060 & 249,641 & 403,319 & 592,743 & 710,795 & 878,866 & $1,096,833$ & $750 \%$ \\
\hline $\begin{array}{c}\text { Density } \\
\left.\text { (individual/km }{ }^{2}\right)\end{array}$ & 3,227 & 2,400 & 2,474 & 2,271 & 2,249 & 2,197 & 2,339 & $-28 \%$ \\
$\begin{array}{c}\text { Density } \\
\text { (individual/ha) }\end{array}$ & 32 & 24 & 25 & 23 & 22 & 22 & 23 & $-28 \%$ \\
$\begin{array}{c}\text { Developed land } \\
\text { per capita (hectares) }\end{array}$ & 0.031 & 0.042 & 0.040 & 0.044 & 0.044 & 0.046 & 0.043 & $38 \%$ \\
\hline
\end{tabular}

Table 3: Historical Population Density from 1951-2011 (Statistics Canada)

Another way to look at population density is by attributing the amount of developed land to one individual or; developed land per capita. It is essentially the inverse of population density yet offers a personalized indicator of how much land is devoted to each person. In 1951, one person consumed about $3 \%$ of one hectare, or about $300 \mathrm{~m}^{2}$ of developed land. By 2011, about $430 \mathrm{~m}^{2}$ of land is developed for every individual; an increase of $38 \%$.

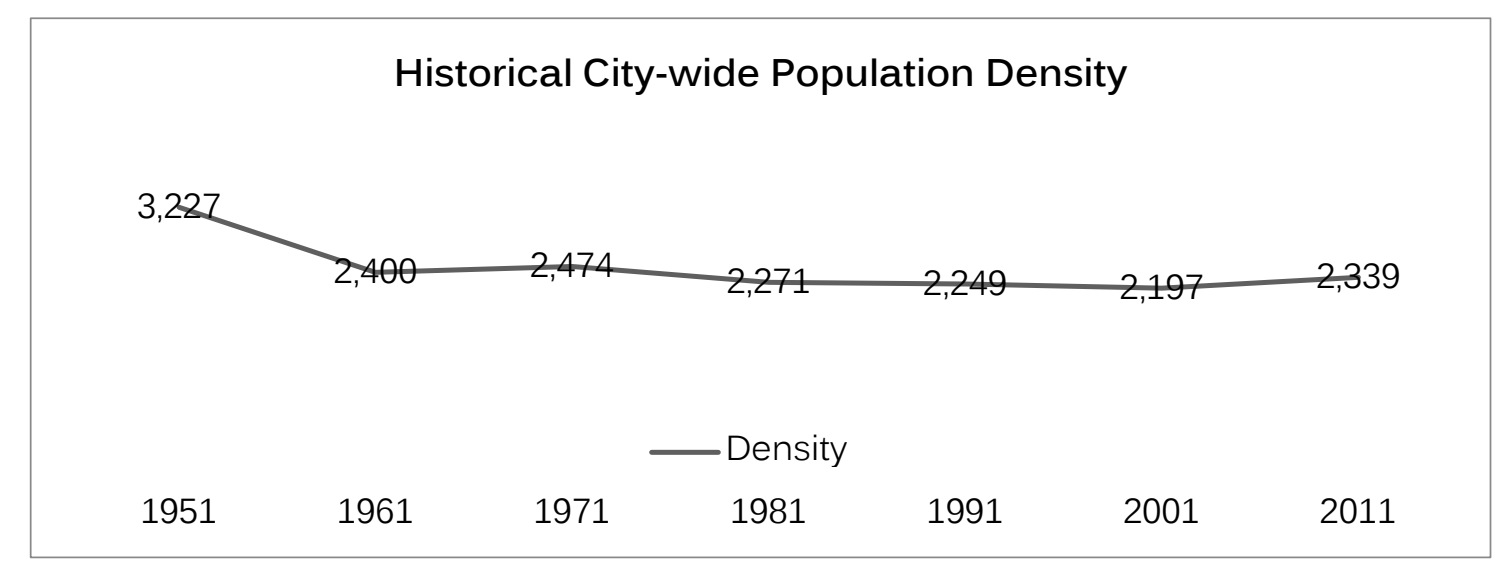

Figure 5: Historical City-wide Population Density

More recent data from Calgary Geodemographics (2014) indicate that population density is continuing to rise and growing at a rate almost equivalent to that of the population growth rate.

Table 4: Density 2011-2014 demonstrates an increase in density of 7 percent from 2011 to 2014. 


\begin{tabular}{cccccc}
\hline & $\mathbf{2 0 1 1}$ & $\mathbf{2 0 1 2}$ & $\mathbf{2 0 1 3}$ & $\mathbf{2 0 1 4}$ & $\begin{array}{c}\text { Growth (\%) } \\
\mathbf{2 0 1 1 - 2 0 1 4}\end{array}$ \\
\hline $\begin{array}{c}\text { Built-up Area } \\
\text { (km 2) }\end{array}$ & 469 & 477 & 477 & 477 & $2 \%$ \\
\hline $\begin{array}{c}\text { Built-up Area } \\
\text { (Ha) }\end{array}$ & 46,900 & 47,700 & 47,700 & 47,700 & $2 \%$ \\
\hline $\begin{array}{c}\text { Population } \\
\text { Density } \\
\left.\text { (individual/km }{ }^{2}\right)\end{array}$ & $1,096,833$ & $1,120,225$ & $1,156,686$ & $1,195,194$ & $9 \%$ \\
\hline $\begin{array}{c}\text { Density } \\
\text { (individual/Ha) }\end{array}$ & 2,339 & 2,348 & 2,425 & 2,596 & $7 \%$ \\
\hline $\begin{array}{c}\text { Developed land } \\
\text { per capita (hectares) }\end{array}$ & 0.043 & 23 & 24 & 25 & $7 \%$ \\
\hline
\end{tabular}

Table 4: Density 2011-2014 (The City of Calgary: Geodemographics, 2014)

The rise in population density offers some evidence that the policies within the MDP are influencing a more compact form. Again, Calgary is still well below the population density numbers of 1950s. The 60-year goal of the MDP is to increase population density to 27 individuals per hectare. Table 4 signifies that the city is making positive progress towards the goal of creating a more dense built form and, based on current trends, should achieve this goal well before the 2076. An opportunity may exist to amend the MDP to increase a higher mandated density based on the argument that it reflects current trends.

\section{Developed vs. Developing Communities}

Another goal of the MDP is to achieve a greater balance of population growth between developed and developing areas of the city. Historically, the majority of the population growth has been distributed in the developing area. Even more troubling, the developing area experienced population gains greater than $100 \%$ in 12 of the last 23 years, meaning that individuals were leaving the developed area for new suburban communities and intensification efforts are struggling to accommodate significant portions of the population. Figure 6, however, 
demonstrates that a dramatic shift occurred in 2012 whereby the developed area began accommodating a significantly larger proportion of the population. Since then, population growth in the developed area has been trending upwards; reaching $43 \%$ in 2014 . This trend highlights that the developed area is absorbing more population growth than at any point experienced throughout the last twenty years. Given this data, it appears that the city has already reached its goal of accommodating 33\% of population growth within the developed area while an opportunity exists to achieve the 2076 goal within a much shorter period of time. The focus now should be on maintaining the split going forward. Taylor et al. (2014) highlight that declining occupancy rates have resulted in housing growth (i.e. dwelling units) has outpaced population growth. This has led, until recently, to a depopulation of developed areas. Intensification of the developed area will be crucial to increase city-wide population density going forward and some of the aforementioned large scale projects should assist the process.

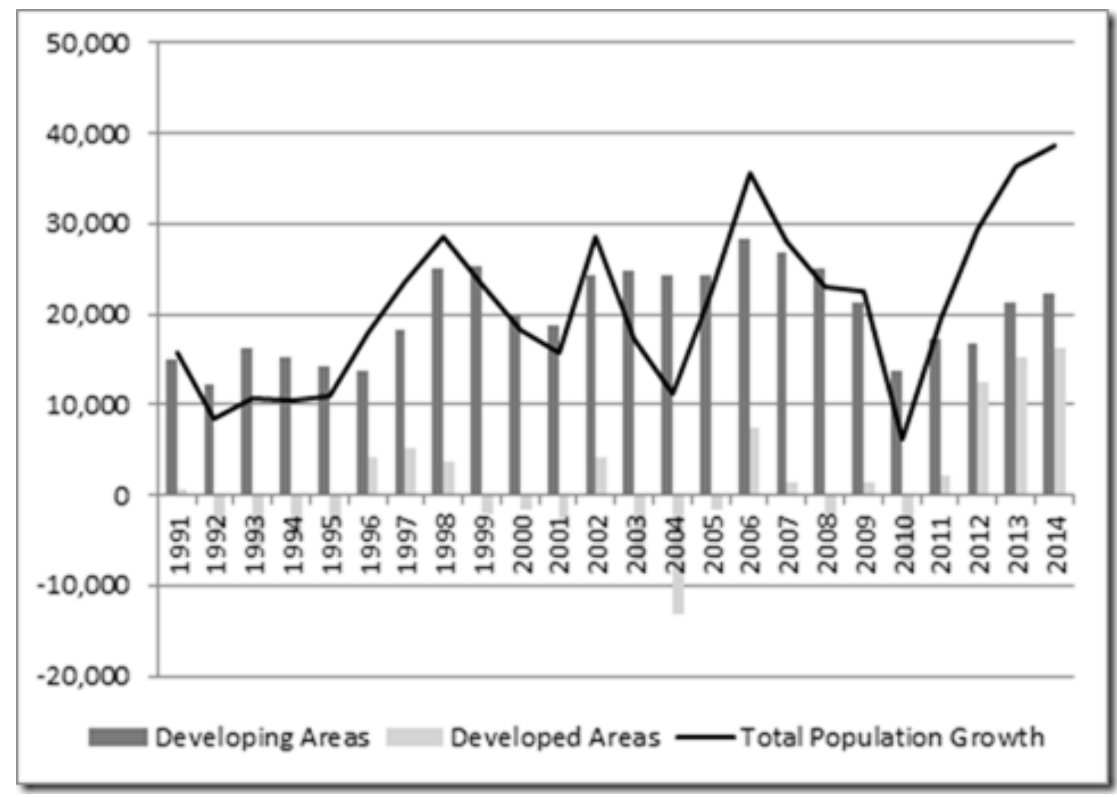

Figure 6: Developed and Developing Areas Share of Population Growth from 1991-2014 (The City of Calgary: Geodemographics, 2014) 


\section{Job Density}

Job density is also an important factor to achieve a more compact urban form. In Calgary, a highly centralized urban core accommodates approximately one quarter of the city's total jobs.

In the central area, densities approach 1,000 jobs per hectare (jph) while greenfield areas experience job densities as low as $5 \mathrm{jph}$ (The City of Calgary: Geodemographics, 2014).

Figure 7 visually depicts Calgary's highly centralized job density. The central city accommodates the majority of jobs,

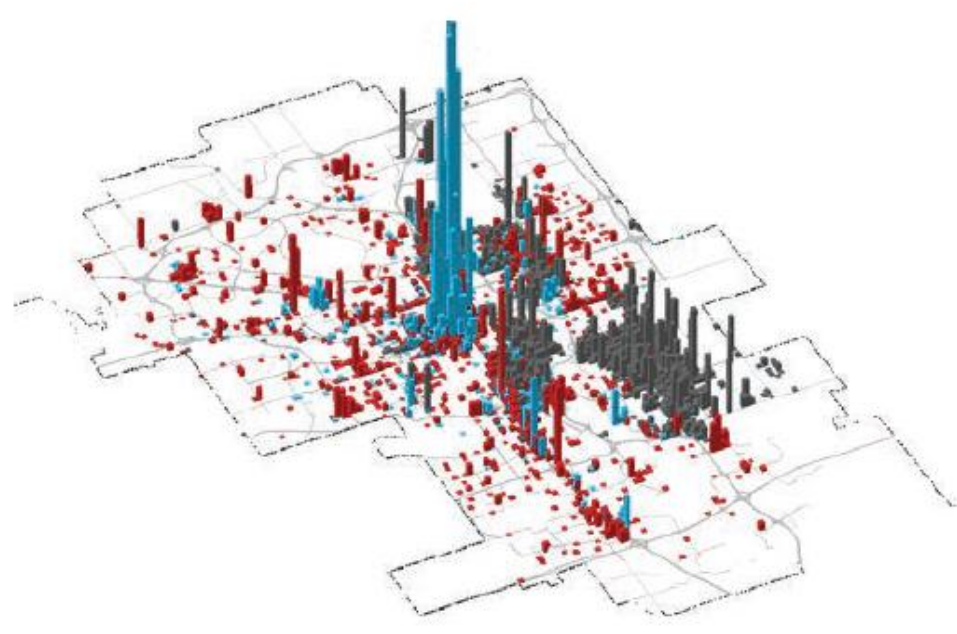

Figure 7: Geographical Distribution of Jobs (City of Calgary, 2011) specifically related to office (blue) while retail (red) is scattered throughout the city, particularly along corridors. Much of the industrial (grey) activity is provided on the eastern edge of the city (The City of Calgary: Geodemographics, 2014). Overall, the city aims to reach an average job density of 18 jobs per hectare by 2076 . Currently, density sits at about 13 jobs per hectare.

Tomalty and Haider (2012) found that new communities built after 1981 contain very few employment opportunities. Job density in communities built before 1981 is approximately six times greater the density employment density of communities built after 1981. The development of the MAC typology is a strategy contained with the MDP signaling a movement away from the dependence on the downtown while offering a greater mix of land uses to discourage dependence on the automobile. The MAC typology applies to development within and outside the built-up area. 


\section{Key Takeaways}

- Calgary is densifying. Trends indicate that population density is increasing city-wide, specifically in new suburban areas where a mandatory minimum density of 20 uph in greenfield exists

- City-wide population density levels are well below 1950 numbers

- New projects such as Currie Barracks and the East Village demonstrate encouraging signs that the city could accommodate significant population increase within the built up area

- Since 2012, a greater share of the overall population increase has been distributed within the developed area.

- Job density is highly concentrated in the core - need to leverage this by continuing to increase the supply of housing near the core and along transit lines

- Housing growth has outpaced population growth which challenges increasing overall population density

- The ability to meet goals regarding a more compact urban form could be a result of strong policy wording in the MDP

- An opportunity may exist to amend the MDP to increase a higher mandated density based on the argument that it reflects current trends

\section{Providing and Promoting a Variety of Transportation Options}

This section examines transportation trends in Calgary using data from Statistics Canada, the American Public Transportation Association and that supplied in City of Calgary reports.

Section 2.5 of the Calgary MDP, "Connecting the City" (2009), identifies a need to develop an integrated, multi-modal transit system that provides alternative transportation options to the automobile. 
Calgary's transit system is separated into both primary and secondary networks. Primary networks provide connected, high frequency service that aims to support the activity centre and corridor typologies specifically. These systems include three Light Rail Transit (LRT) routes covering $56 \mathrm{~km}$ and a BRT system totaling $25 \mathrm{~km}$. Continuous investments in the LRT have occurred as the city expands geographically. In addition, The City continues to plan for networks with the aim of supplying $26 \mathrm{~km}$ of LRT transit to the north-central and southeast populations (City of Calgary, 2013). Figure 8: Investment in Transit Infrastructure since 2001 depicts transit upgrades since 2001, illustrating major primary network upgrades in the last 14 years. A base transit system supplements the primary network with a number of feeder routes. Other alternative transportation networks include a regional pathway systems and, as of 2015, a separated cycle track network in the city centre.

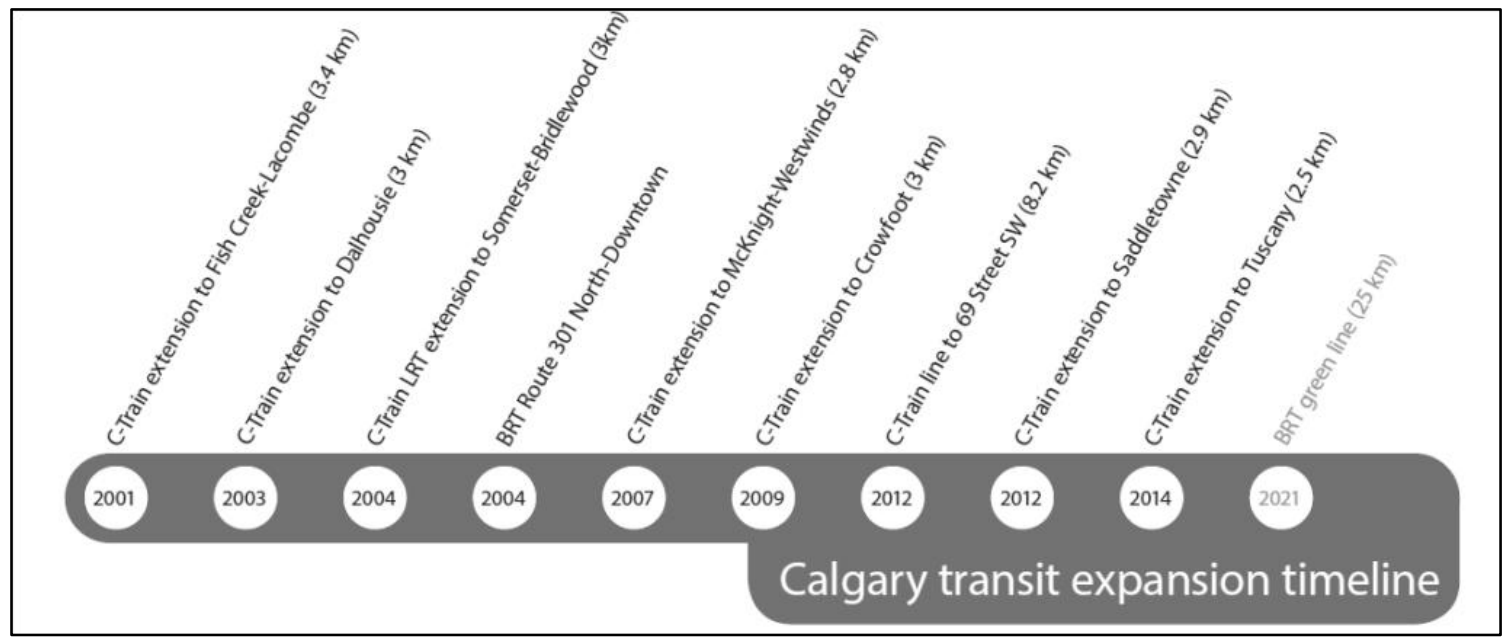

Figure 8: Investment in Transit Infrastructure since 2001 (Pembina Institute, 2014) 
The literature highlights transportation, along with density, as being the cornerstone policy areas of Smart Growth and that transportation investments heavily influence development patterns (Cervero, 2001; Ingram et al., 2009). Ingram et al. (2009) conclude that the transportation land-use connection is important to the Smart Growth movement in two ways. Firstly, advocates often oversimplify the connection, assuming that greater densities, the mixing of uses and multimodal options will produce gains in non-automobile travel. Second, even the most successful Smart Growth initiatives are likely to have limited impacts on transportation outcomes. Studies have shown that preferences influence travel more than land-use plans and urban design interventions. Cervero (2001) argues that land-use plans are a "second best" solution to address congestion and transportation problems. The overall implications of these findings are that Smart Growth goals related to transportation must be part of a broader strategy that addresses the market and consumer preferences. The City formally integrates transportation and land use planning together, however, the following analyses seeks to understand if Calgary has been able to provide and promote a variety of different transit options in the city.

\section{Commuters by Transit from 1996-2013}

Calgary Transit ridership is steadily trending upwards and, in 2013, the city experienced the highest ridership to date. In 2013, 167 million transit trips were completed through a combination of bus and LRT use. Figure 9: Calgary (Bus+LRT) Transit Ridership from 1996-2013 reflects total bus and LRT transit trips from 1996-2013 while the trend line reflects total trips. 


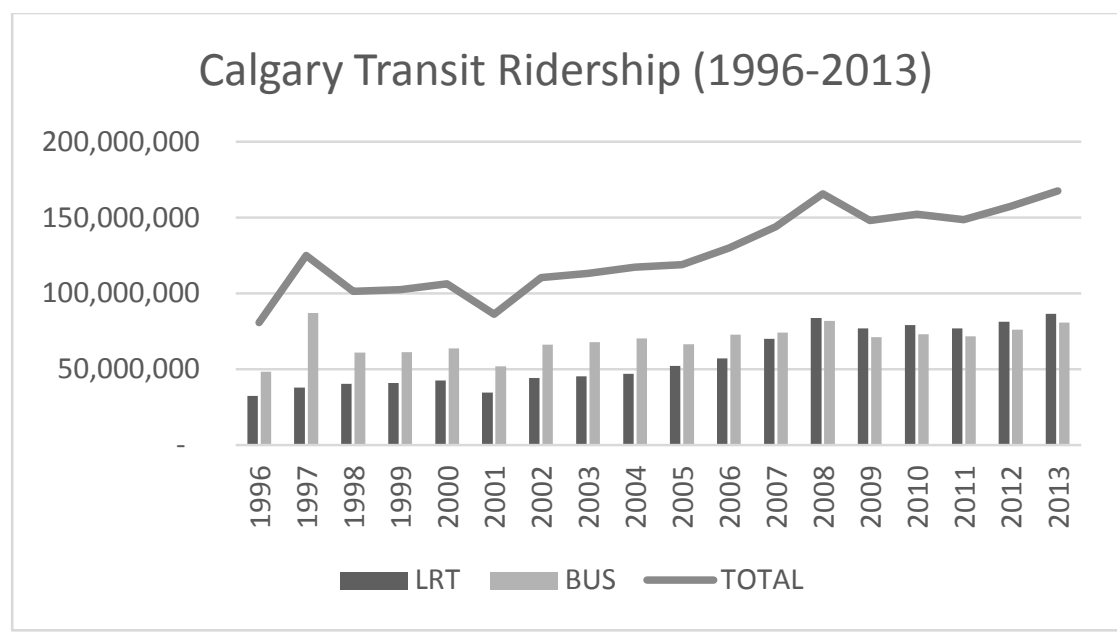

Figure 9: Calgary (Bus+LRT) Transit Ridership from 1996-2013 (American Public Transportation Association, 2014)

Since 2009, transit ridership has been growing more rapidly than the population growth rate indicating that a greater proportion of individuals are utilizing the transit network for travel. Table 5 highlights this trend. Although it is unclear if this is the direct result of policies relating to the MDP or CTP, it is an encouraging sign that Calgary is providing and promoting options, through strategic investments, that are resulting in growing transit ridership. Approximately 145 transit trips per individual were generated in 2013. The City's strict downtown parking policy has led to some of the most expensive parking in North America making transit a relatively inexpensive transportation alternative (Tomalty \& Alexander, 2005).

\begin{tabular}{ccccccc}
\hline & $\mathbf{2 0 0 9}$ & $\mathbf{2 0 1 0}$ & $\mathbf{2 0 1 1}$ & $\mathbf{2 0 1 2}$ & $\mathbf{2 0 1 3}$ & $\begin{array}{c}\text { Growth } \\
(\mathbf{2 0 0 9 - 2 0 1 3 )}\end{array}$ \\
\hline Population & $1,065,455$ & $1,071,515$ & $1,096,833$ & $1,120,225$ & $1,156,686$ & $\mathbf{8 \%}$ \\
Transit Ridership & $148,211,200$ & $152,334,500$ & $148,546,000$ & $157,325,300$ & $167,536,000$ & $\mathbf{1 2 \%}$ \\
$\begin{array}{c}\text { Transit Ridership } \\
\text { (Per Capita) }\end{array}$ & 139 & 142 & 135 & 140 & 145 & $\mathbf{4 \%}$ \\
\hline
\end{tabular}




\section{Mode share}

One of the overarching goals of Smart Growth is to decrease the reliance on the automobile and encourage more sustainable forms of transportation such as walking, cycling, and transit. While the road network is a vital piece of infrastructure within an integrated transportation network, the MDP moves to lessen the city's dependence on the private automobile. As demonstrated in the last discussion, transit-use is increasing in the city; however, as shown in Figure 10, roads are still the dominant transportation network using private automobiles as the mode. In fact, car-dependency grew in relation to other modes of transportation in Calgary from 2005-2011. Mode share based on surveys conducted by the City of Calgary highlight the increase while data retrieved from Statistics Canada confirm the city's findings. The numbers are based on all purpose city wide trips and reflect a

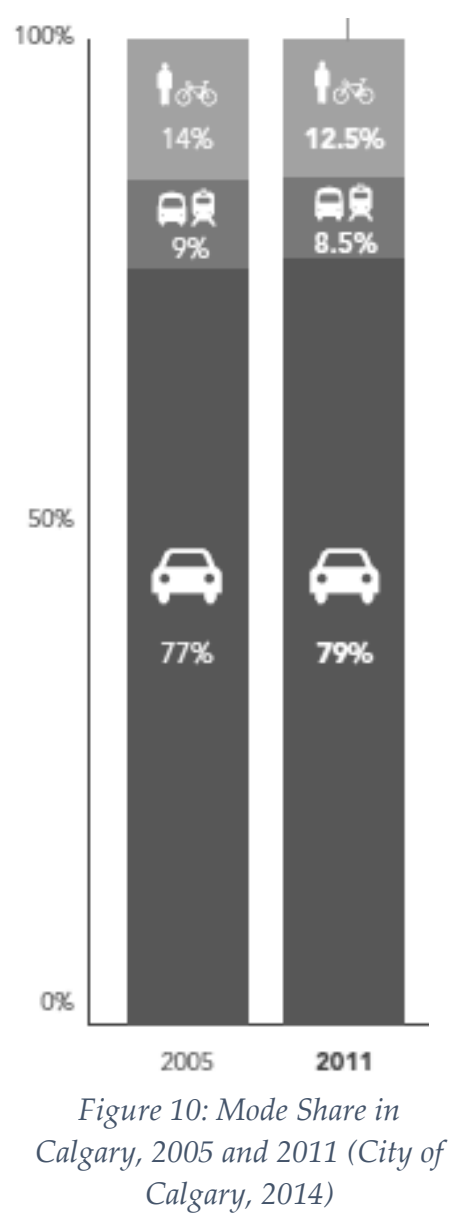
troubling realization that Calgary has been unable to move away from the city's dependence on the automobile. The data highlights the challenge faced by the city in order to achieve the goal of the MDP which intends to reduce auto trips as a share of all transportation trips to $60 \%$ by 2076. One promising statistic is that auto trips significantly decrease when density increases. This is reflected by reduced auto trips in the City Centre, Activity Centre, and Inner City typologies. In the City Centre, active transportation and transit make up 65\% of all trips (The City of Calgary: Geodemographics, 2014). Overall, city-wide mode share is an indicator that signifies a hesitance from Calgarians to move away from auto dependency. 


\section{Key Takeaways}

- Significantly high transit ridership per capita that is increasing faster than the population growth rate

- The automobile is the dominant mode of transportation, slightly increasing its relative share from 2006-2011

- Areas of higher density are experiencing less automobile reliance (e.g. City Centre and Beltline neighbourhoods)

- Jobs in the industrial employment areas lack access to primary transit networks.

\section{Supply of Affordable Housing}

This section examines affordable housing trends in Calgary leveraging Statistics Canada census data and secondary research conducted by Tomalty, Alexander and Haider (Tomalty \& Alexander, 2005; Tomalty \& Haider, 2008). Section 2.3 of the Calgary MDP, “Creating Great Communities" (2009), identifies a need to provide a variety of housing option in a manner that creates an opportunity for more affordable options. The City, while not directly responsible for the majority of housing provided in the city, has an opportunity to shape delivery through the application of good planning policy and zoning that complements the market. Tomalty and Alexander state that "local government has an important role to play through its influence over urban form, planning and engineering standards, parking requirements, municipal charges and taxes, the liquidation of public lands, property taxes, the project approval process, and handling citizen opposition to affordable housing through public consultation" (2005, p. 213).

Smart Growth policy, like any other municipal policy affecting land use, has the ability to influence affordable housing. For many years, as Tomalty and Haider (2008) state, a “key 
method used in Calgary to ensure housing price stability has been the periodic annexation of lands from surrounding jurisdictions (the UniCity concept) and the orderly expansion of suburban areas. The resulting development patterns, however, have also begun to raise concerns." As mentioned in section 2, the sprawling development pattern is beginning to escalate both municipal capital and operating costs. A key argument regarding the benefits of sprawl is that it provides affordable housing options and a common argument against smart growth is that by limiting the supply of greenfield land, through growth management policy, the housing supply is reduced, therefore housing prices increase. Nelson (2002) found that this view is far too simplistic and that many factors contribute to housing prices, specifically market demand which is a function of population growth. The results are echoed in Calgary, based on Tomalty and Haider's (2008) analysis on the connection between Smart Growth and housing affordability in Calgary, who found that supply side variables are limited determinants of house prices. Their research, informed by the literature, indicates that municipal policy has a minimal effect on housing affordability in which they argue:

"Cities that attempt to moderate outward growth may put a gentle upward pressure on the market value of land and homes, but it is the increased desirability (the so called "amenity value") of cities with effective growth management processes that is preeminent in influencing prices. The most promising approach to affordability and growth management issues is to integrate housing affordability policies into a Smart Growth framework and promote intensification of established areas, less expensive housing forms and development control regulations and processes that reduce development 
costs and encourage a greater supply of moderately priced housing units" (Tomalty \& Haider, 2008, p. 49).

Another important piece to consider when analysing affordable housing is the federal government's reduced role in the provision of affordable housing since 1993 and that the majority of individuals secure housing through the private market (Hulchanski, 2007). Tomalty and Alexander (2005, p. 65) note that "there has been little addition to the subsidized housing stock since 1993, when the Provincial and Federal governments substantially reduced the capital funding of affordable housing." The following analysis considers this while presenting indicators to illustrate housing trends in Calgary.

\section{Housing Cost and Income Trends}

Housing values in Calgary have increased significantly in the period between 1991 and 2011. Table 6: Median Value of Dwelling Relative to Income Growth (1991-2011) displays that the median value of a dwelling in the city has increased by $177 \%$ from $\$ 144,477$ in 1991 to $\$ 400,697$ in 2011. During the same period, median income for individuals and households increased by $75 \%$ and $95 \%$ respectively. Housing values have risen faster than income levels in the city indicating that housing may have become less affordable over the stated period of time.

\begin{tabular}{lccc}
\hline & $\mathbf{1 9 9 1}$ & $\mathbf{2 0 1 1}$ & Change (\%) \\
\hline Median Value of Dwelling (\$) & $\$ 144,477$ & $\$ 400,697$ & $177 \%$ \\
Median Individual Income (\$) & $\$ 21,582.00$ & $\$ 37,697.00$ & $75 \%$ \\
Median Household Income & $\$ 50,249.00$ & $\$ 97,790.00$ & $95 \%$ \\
\hline
\end{tabular}




\section{Cost Burdened Households}

Cost burdened, also known as those in core housing need, is defined as those households that contribute more than $30 \%$ of their income to shelter (CMHC, 2014). Using this indicator, it is clear that housing affordability for both renters and owners is declining. Figure 11 highlights that the percentage of cost burdened households have increased over the period from 1991 to 2011. Although still increasing significantly, the percentage of cost burdened home owners shifted upwards at a steadier pace. The affordability issue is strikingly different for renters. The percentage of cost burdened renters from 1991 to 2011 increased by 177\%. This happened twice in a 20 year period, notably when the Calgary economy was doing well and large population increases occurred. Tomalty and Alexander offer an explanation for the rental affordability problem after finding similar results in 2005. They state that the rental affordability problem is "due largely to the failure of the private market to deliver new rental stock, the demolition of existing rental stock or conversion to condos, a buoyant economy that has bolstered inmigration causing a higher demand for rental housing, and Alberta's low minimum wage and social assistance rates" (2008, p. 65). Although the minimum wage has increased since then, similar affordability problems remain. 


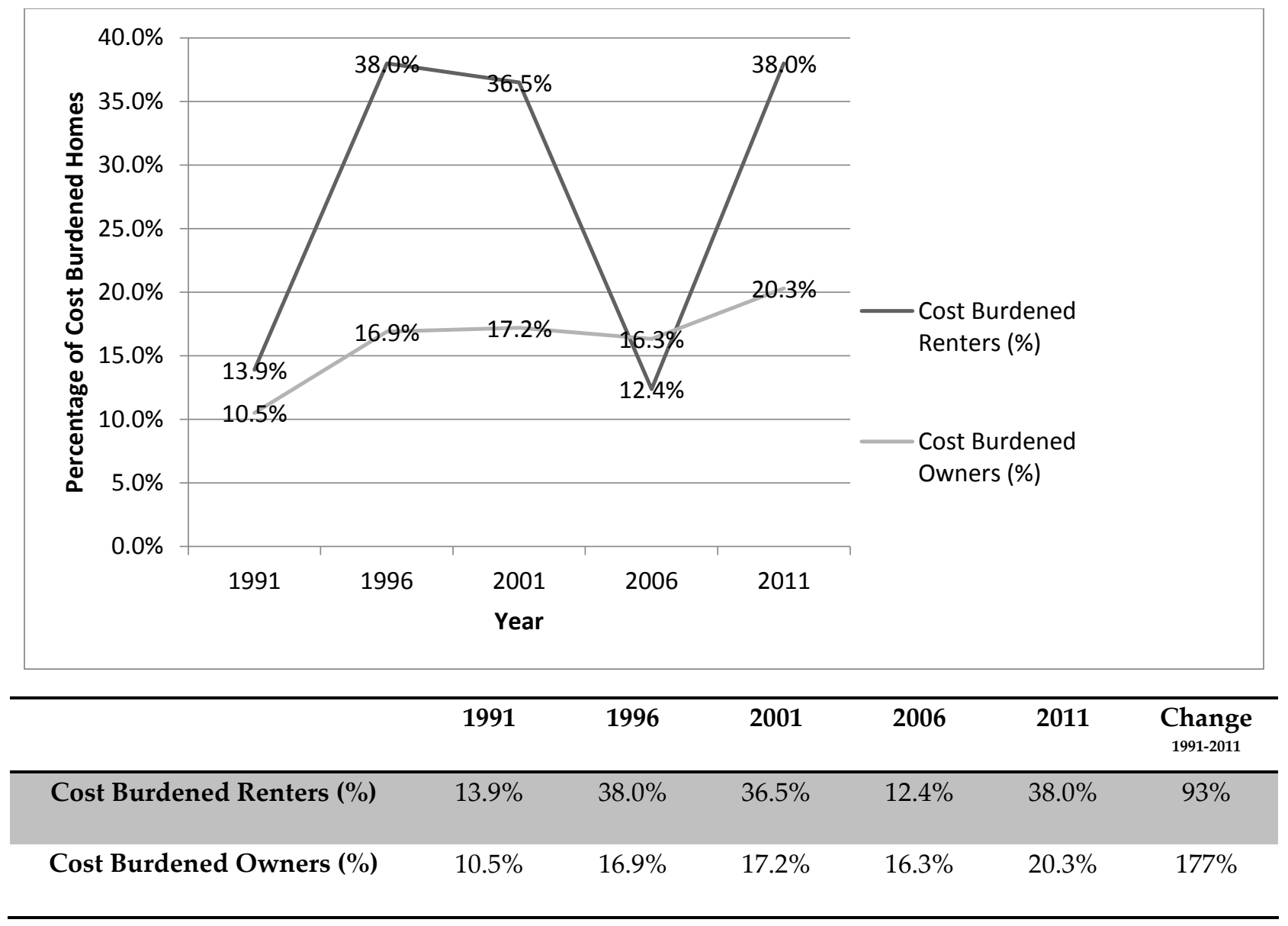

Figure 11: Cost Burdened Households from 1991-2011 (Statistics Canada, 2014)

These indicators point to housing affordability as a pressing issue in Calgary. The proliferation of cost burdened households is troubling because the data suggests that a greater proportion of households are spending more than $30 \%$ of their income on housing than ever before. It is important to highlight that this may be a national trend. In 2011, about $25 \%$ of all households in Canada spent more than 30\% on housing (Statistics Canada, 2011) highlight a macro level problem; nonetheless, civic policy should not intensify the issue. 


\section{Housing Mix}

While the analysis in the previous section indicates that housing affordability in Calgary is declining, growth management policy and supply side factors play a minimal role in influencing it. One finding of Tomalty and Haider's (2008) research in Calgary is that house prices are positively correlated with single detached homes and negatively correlated with more dense housing forms like row and townhouses (defined in the MDP as ground-oriented dwellings). This means that housing tends to be less affordable in areas with a greater proportion of single family homes, and more affordable in areas with ground-oriented housing. This type of housing includes multi family, town, semi-detached and row houses. For this reason, housing mix is a useful measure to further analyse housing affordability in Calgary.

Figure 12: Housing Mix from 1993 to 2013 demonstrates signs that more ground-oriented homes are being built in Calgary. In theory, supported by Tomalty and Haider's empirical research, this situation should contribute to an affordable housing environment in Calgary. 


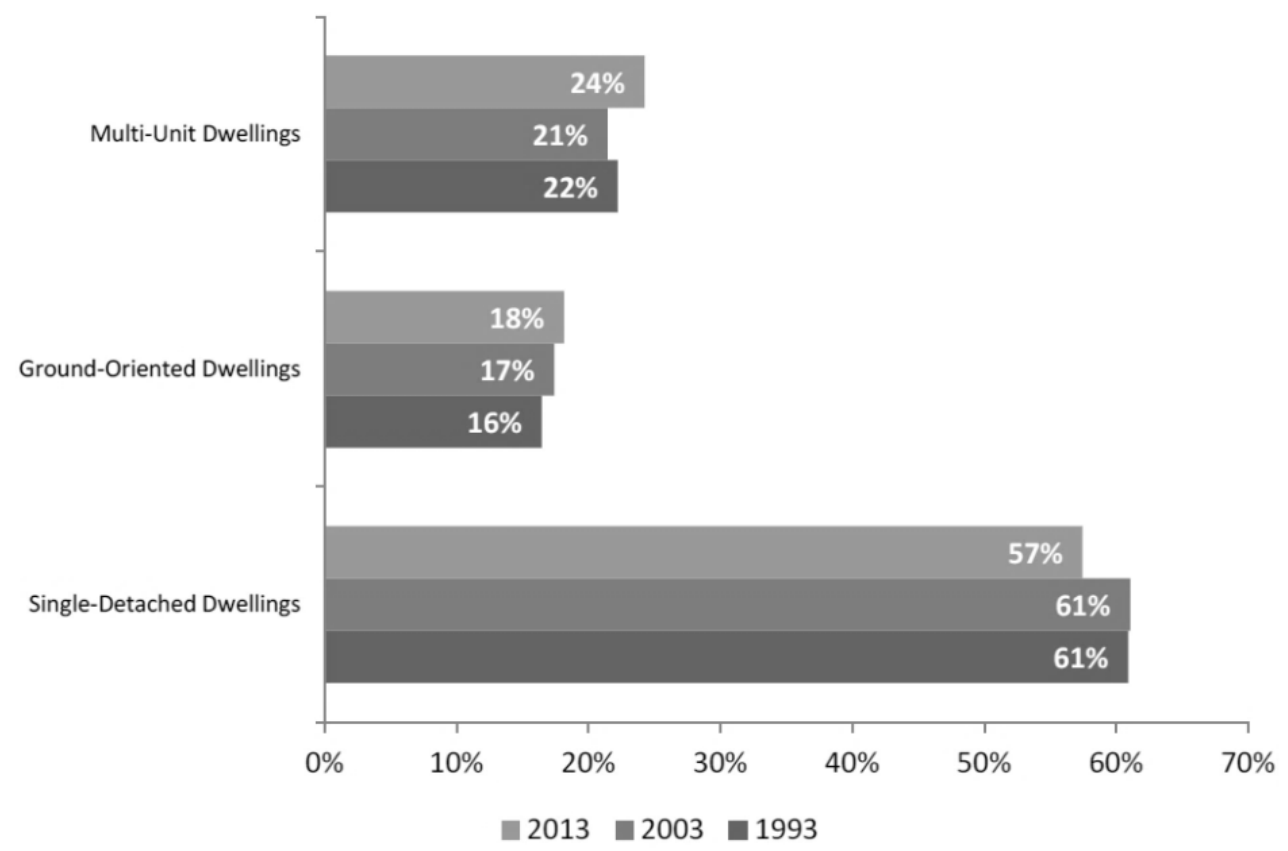

Figure 12: Housing Mix from 1993 to 2013

\section{Key Takeaways}

- Overall housing affordability is an issue in Calgary

- City policy plays a minimal role in the housing market as research suggest that price is more influenced by demand

- Calgary is offering a more diverse mix of housing options. Based on Tomalty and Haider's research this should increase housing affordability.

- Indirect policy wording in the MDP around affordable housing. Does not directly set targets for new developments rather encourages a "mix of uses" and "intensification" 


\section{Final Discussion and Recommendations}

Overall, the literature reviews and Smart Growth analysis indicate that Calgary is struggling to meet second two of the following three goals of Smart Growth analyzed in this study:

1) Promoting Compact Development - Building where infrastructure and development already exist by increasing density.

2) Providing and Promoting a Variety of Transportation Options - connecting land uses with transportation alternatives to the car.

3) Supply Affordable Housing - enhancing affordability and increasing options.

A fourth overarching challenge relating to the effectiveness of regional governance structures became increasingly apparent in the research. The challenges highlighted in this study are typical, given research conducted by Downs (2005) on the barriers to implementing Smart Growth. His work will be used to frame parts of the following discussion.

Table 7 summarizes the key findings from the literature reviews and analysis. Trends have been categorized based on the corresponding element of Smart Growth and branded as being either positive or negative. Overarching trends emerged throughout the study, specifically the literature reviews, and could not be categorized into one of the key elements analyzed. Recommendations are provided following a discussion of each section. 


\section{Overarching Issue - Regional Planning}

Issues around regional planning became apparent in the study. A lack of support from the Provincial Government became evident and the decline of Calgary's regional proportion of the population are concerning. Regarding these challenges, one hypothesis is that Calgary and the satellite municipalities are struggling to collaborate on regional planning issues. Further research is required to substantiate this claim; however, I suspect that MDPs are not aligned while each municipality focuses on its corresponding goals in a silo. This is a key issue that needs to be understood because it has the overarching potential to undermine Calgary's Smart Growth goals.

Downs highlights this as a major challenge for municipalities striving to implement Smart Growth policy. He argues that “several key Smart Growth principles require government action at a regional level, not at the local level where most powers over land use planning now reside" (Downs, 2007, p. 369).

Therefore, I recommend that the City of Calgary, while continuing to collaborate with satellite communities in an effort to align goals, lobby the Provincial Government to ensure that a regional planning strategy is in place for the Calgary Metropolitan Region by 2019. The strategy can be developed through the use of legislation or incentives but should meet this timeframe in order to inform the City of Calgary's MDP review. 


\begin{tabular}{|c|c|c|}
\hline Element of Smart Growth & Positive & Negative \\
\hline Overarching & $\begin{array}{l}\text { - Some indications that the Province is } \\
\text { moving to become more involved in } \\
\text { regional planning }\end{array}$ & $\begin{array}{l}\text { - Long history of sprawl engrained within } \\
\text { the cultural mindset of Calgary's } \\
\text { citizens, developers, and Council } \\
\text { members } \\
\text { - Lack of regional guidance stemming } \\
\text { from } 1995 \text { abolishment of formalized } \\
\text { RPCs } \\
\text { Excessive growth in suburban } \\
\text { communities such as Airdrie, Cochrane, } \\
\text { and Chestermere have the potential to } \\
\text { undermine Smart Growth initiatives in } \\
\text { Calgary } \\
\text { Lack of regional planning authority to } \\
\text { encourage and direct Smart Growth in } \\
\text { the Calgary Metropolitan Region }\end{array}$ \\
\hline Promoting Compact Development & $\begin{array}{l}\text { Calgary is densifying. Trends indicate } \\
\text { that density is increasing city-wide, } \\
\text { specifically in new suburban areas } \\
\text { The ability to meet goals regarding a } \\
\text { more compact urban form could be a } \\
\text { result of strong policy wording in the } \\
\text { MDP } \\
\text { - New projects such as Currie Barracks } \\
\text { and the East Village demonstrate } \\
\text { encouraging signs that the city could } \\
\text { accommodate significant population } \\
\text { increase within the built up area } \\
\text { Since 2012, a greater share of the overall } \\
\text { population increase has been distributed } \\
\text { within the developed area. }\end{array}$ & $\begin{array}{l}\text { - City-wide population density levels well } \\
\text { below } 1950 \text { numbers } \\
\text { - Job density is highly concentrated in the } \\
\text { core - need to leverage this by } \\
\text { continuing to increase the supply of } \\
\text { housing near the core. }\end{array}$ \\
\hline $\begin{array}{l}\text { Providing a Variety of } \\
\text { Transportation Options }\end{array}$ & $\begin{array}{l}\text { Significantly high transit ridership per } \\
\text { capita that is increasing faster than the } \\
\text { population growth rate } \\
\text { Areas of higher density are experiencing } \\
\text { less automobile reliance (e.g. City Centre } \\
\text { and Beltline neighbourhoods) }\end{array}$ & $\begin{array}{l}\text { The automobile is the dominant mode of } \\
\text { transportation, slightly increasing its } \\
\text { relative share from 2006-2011 } \\
\text { Jobs in the industrial employment areas } \\
\text { lack access to primary transit networks. }\end{array}$ \\
\hline Supply Affordable Housing & $\begin{array}{l}\text { Calgary is offering a more diverse mix of } \\
\text { housing options which, supported by } \\
\text { research, could enhance affordability }\end{array}$ & $\begin{array}{l}\text { - Overall housing affordability is an issue } \\
\text { in Calgary } \\
\text { - Indirect policy wording in the MDP } \\
\text { around affordable housing. Does not } \\
\text { directly set targets for new } \\
\text { developments rather encourages a "mix } \\
\text { of uses" and "intensification" } \\
\text { - City policy plays a minimal role in the } \\
\text { housing market }\end{array}$ \\
\hline
\end{tabular}




\section{Promoting Compact Development}

The analysis indicates that Calgary is progressing towards the goal of promoting a more compact form of development. Population and employment density appear to be increasing in Calgary. As one of the primary goals of Smart Growth, this is a very good sign. A reason for this, I would argue, is that the MDP policies containing density goals have strong wording such as "must" and "will." These policies mandate Local Area Plans to demonstrate an ability to meet higher density standards. Recent data in the analysis suggests that the City could potentially reach its targeted residential density within the next few years and is also well positioned to meet employment density targets within a shorter time period. The City needs to focus on accommodating population increases within the built up area in order to meet the targeted 50/50 split by 2076. Larger intensification projects highlight the potential for this to occur although established communities, not currently serviced by major transit routes, will face intensification challenges.

Down's (2007) argues that municipalities need to understand the Smart Growth - urban sprawl paradox. He states that citizens will oppose urban sprawl in the abstract but oppose density increases that are planned near their homes. Because of this, increasing residential population density is seen as a critical problem for carrying out the goals of Smart Growth. While Calgary has recently performed well in increasing density, specifically in greenfield areas, a continuing effort is needed. Therefore I recommend amending the MDP in two ways:

a. Adjust the target under Core Indicator \#2 to reflect a higher density for people and jobs per hectare. 
b. Adjust Section 2.2 of the "New Community Planning Guidebook" to reflect higher densities in Greenfield areas.

Pending approval, these policy amendments will further signify to the public and industry that increasing density is important to the City of Calgary. The majority of Calgary's growth is expected to occur in the suburbs; therefore, establishing high densities in greenfield developments can mitigate Downs' Smart Growth-urban sprawl paradox by reducing the need for intensification in the future. Establishing a stable balance of growth between the developing and developed areas can also reduce unnecessary outward expansion. Increasing intensification within the city will give Calgary an opportunity to provide higher order transit.

\section{Providing a Variety of Transportation Options}

The analysis indicates that Calgary is struggling towards meeting its goal of providing more transportation options for citizens. Calgary is essentially an automobile city which creates significant challenges for progressing towards Smart Growth goals as whole because it is identified as one of the primary goals. Transit ridership is strong given the city's centralized core which contains a significant number of employment opportunities. This is enhanced by The City's stringent stance on parking provision within the core (Tomalty \& Alexander, 2005). Further research is required in order to understand how the city can move away from the automobile. Based on the analysis contained within this report, I would argue that mode share is a function of density and that increases will enhance the shift towards alternative transportation modes. One such policy would be increasing density in transit station planning areas. Currently, these areas are planned to reflect a minimum density of 100 people and jobs per hectare reflecting a balance medium density threshold. This could be adjusted to 
accommodate a high density threshold of 200 people and jobs per hectare, therefore I recommend amending Section 2.9.3a of the New Community Planning Guidebook within the MDP to read "Developments in each TPSA shall achieve a minimum intensity of 200 people and jobs per gross developable hectare." Overcoming automobile dependency will be challenging and a more comprehensive strategy will need to be developed that integrates both the regional and local levels.

\section{Supply Affordable Housing}

The analysis indicates that Calgary is struggling towards the goal of providing an affordable supply of housing. Calgary does appear to be encouraging an appropriate level of mix to improve housing affordability, however; the literature identifies housing affordability as being a macro level issue which includes a variety of price determinants that are not directly related to local policy. Nonetheless, local policies should support affordable options. Relating to housing, loose policy language in the MDP highlights some room for improvement. The MDP is full of terms such as "encourage," "recognize" and "promote," in seeking new and innovative housing types. An innovative option is to approve strategies such as density bonuses, laneway housing and secondary suites. Such approaches create the potential for intensification in established neighbourhoods. While demonstrating support from some Members of Council, including the Mayor, secondary suites have failed to be approved in any significant form indicating that the entire city is not willing to support the option. Based on the analysis contained within this paper, there is room to improve planning policy related to affordable housing. Therefore I 
recommend that The City explore the potential for adopting policy that mandates a certain percentage of new developments to contain affordable housing units. 


\section{Conclusion}

Urbanization will continue, suburban growth will occur, and the automobile will linger as a major form of transportation in the foreseeable future. The literature demonstrates that urban sprawl is costly problem; one that has shaped Calgary's urban form since the post-war period.

Thus far Calgary cannot be considered a Smart Growth success story as many challenges remain. The city, however, will be an interesting case study going forward. The Smart Growth movement and its associated principles are playing a role in shifting Calgary's urban growth trajectory. Portions of the analysis in this report present encouraging signs that the next 50 years of growth may in fact be different. The city is becoming denser, transit ridership is increasing, and a greater mix of housing is being offered. I have recommended policy changes for Calgary's Municipal Development Plan; however, as the overall region continues to grow, a provincial role may become increasingly vital. Given the costs of sprawl, Smart Growth options will likely be pursued by an increasing number of municipalities. What remains unclear is exactly how long it will take and which stakeholders will lead the charge. 


\section{References}

Alberta Government. (2014). South Saskatchewan Regional Plan. Edmonton: Alberta Government: Environment and Sustainable Resource Development.

Alberta Government. (2015). Municipal Government Act Review: Emerging Themes: A Summary of Municipal Partner and Stakeholder Considerations. Edmonton: Alberta Government.

American Public Transportation Association. (2014). Ridership Report Archives 1996-2014. Washington: American Public Transportation Association.

Blais, P. (2010). Perverse Cities. Vancouver: UBC Press.

Brookings Institute. (2014). Global Metro Monitor. Retrieved from Brookings: http://www.brookings.edu/research/reports2/2015/01/22-global-metro-monitor

Brueckner, J. (2000). Urban Sprawl: Diagnosis and Remedies. Urbana-Champaign: International Regional Science Review.

Bullard, R. (2007). Growing Smarter: Achieving Livable Communities, Environmental Justice, and Regional Equity. Cambridge: MIT Press.

Burchell, R. (2002). Costs of Sprawl. Washington: National Academy Press.

Burchell, R. W., Downs, A., McCann, B., \& Mukherji, S. (2005). Sprawl Costs: Economic Impacts of Unchecked Development. Washington: Island Press.

Burchell, R., Listoken, D., \& Galley, C. (2000). Smart Growth: More Than a Ghost of Urban Policy Past, Less Than a Bold New Horizon. Housing Policy Debate, 821-879.

Calgary Regional Partnership. (2014). Calgary Metropolitan Plan. Calgary: Calgary Regional Partnership .

Campbell, S. (1996). Green Cities, Growing Cities, Just Cities? Journal of the American Planning Association, 296-309.

Cervero, R. (2001). Efficient Urbanisation: Economic Performance and the Shape of the Metropolis. Urban Studies, 1651-1671.

Chapin, T. (2012). From Growth Controls, to Comprehensive Planning, to Smart Growth: Planning's Emerging Fourth Wave. Journal of the American Planning Association, 5-15.

City of Calgary. (2007). imagineCALGARY Plan: For Long Range Urban Sustainabilty. Calgary: City of Calgary.

City of Calgary. (2009). Municipal Development Plan. Calgary: City of Calgary . 
City of Calgary. (2013). Route Ahead: A Strategic Plan for Transit in Calgary. Calgary: The City of Calgary.

City of Calgary: Geodemographics. (2014). Developed Areas Growth and Change 2014. Calgary: The City of Calgary.

CMHC. (2014). Housing in Canada: Definition of Variables. Retrieved from Canada Mortgage and Housing Corporation: http://cmhc.beyond2020.com/HiCODefinitions_EN.html\#_Core_Housing_Need_Status

Cox, W. (2007). The Argument Against Smart Growth. Planetizen Contemporary Debates on Urban Planning, pp. 10-17.

Degrove, J. (2005). Planning Policy and Politics: Smart Growth and the States. Washington: Lincoln Institute of Land Policy.

Dierwechter, Y. (2008). Growth Management and its Discontents: Promises, Practices, and Geopolitics in U.S. City-Regions. New York: Palgrave Macmillan.

Downs, A. (2007). Smart Growth: Why We Discuss It More than We Do It. Journal of the American Planning Association, 367-378.

Flint, A. (2007). A Tipping Point - But Now the Hard Part. Planetizen Contemporary Debates on Urban Planning, pp. 6-9.

Foran, M. (2009). Expansive Discourses: Urban Sprawl in Calgary, 1945-1978. Calgary: Athabasca University Press.

Frumkin, H. (2002). Urban Sprawl and Public Health. Public Health Reports, 202-217.

Galster, G. (2001). Wrestling Sprawl to the Ground: Defining and Measuring an Elusive Concept. Housing Policy Debate, 681-717.

Ghitter, G. (2008). Mad Cows, Regional Governance, and Urban Sprawl. Urban Affairs Review, 128.

Goetz, A. (2013). Suburban Sprawl or Urban Centres: Tensions and Contradictions of Smart Growth Approaches in Denver, Colorado. Urban Studies, 2178-2195.

Gordon, D., \& Janzen, M. (2013). Suburban Nation? Estimating the Size of Canada's Suburban Population. Journal of Architectural and Planning Research, 197-219.

Gordon, D., \& Vandyk, C. (2006). Suburban National Capital: A Pilot Study of Canada's Post 1945 Suburbs in Ottawa-Hull. Kingston: Queens University .

Hulchanski, D. (2007). What Factors Shape Canadian Housing Policy? The Intergovernmental Role in Canada's Housing System. Montreal: McGill-Queen's University Press. 
Ingram, G. K., Carbonell, A., Hong, Y.-H., \& Flint, A. (2009). Smart Growth Policies. Cambridge, MA: Lincoln Institute of Land Policy.

Lewis, P. G., \& Baldassare, M. (2010). The Complexity of Public Attitudes Towards Compact Development. Journal of the American Planning Association, 219-237.

Nelson, A. C., \& Dawkins, J. C. (2004). Urban Containment in the United States: History, Models, and Techniques for Regional and Metropolitan Growth Management. Washington: American Planning Association.

Nelson, A. C., \& Peterman, D. R. (2000). Does Growth Management Matter? The Effect of Growth Management on Economic Performance. Journal of Planning Education and Research, 277-285.

Nelson, A. C., Pendall, R., Dawkins, C. J., \& Knaap, G. J. (2002). The Link Between Growth Management and Housing Affordability: The Academic Evidence. Washington: The Brookings Institute.

Neuman, L. (2006). Social Research Methods: Qualitative and Quantitative Approaches. Boston: Pearson Education Inc.

Neuman, M. (2005). The Compact City Fallacy. Journal of Planning Education and Research, 11-26.

Ontario Ministry of Municipal Affairs and Housing. (2006). Growth Plan for the Greater Golden Horseshoe. Toronto: Government of Ontario.

Pembina Institute. (2014). Fast Cities: A comparison of rapid transit in major Canadian cities. Ottawa: Pembina Institute.

Pembina Institute. (2015). Location Matters: Factoring location costs into homebuying decisions. Toronto: Pembina Institute and RBC.

Statistics Canada. (1961). CHASS: Canadian Census Analyser. Retrieved from Canadian 1961 Census Profile (Census Tract level): http://dc1.chass.utoronto.ca.ezproxy.lib.ryerson.ca/census/1971_ct.html

Statistics Canada. (1971). CHASS: Canadian Census Analyser. Retrieved from Canadian 1971 Census Profile (Census Tract level): http://dc1.chass.utoronto.ca.ezproxy.lib.ryerson.ca/census/1971_ct.html

Statistics Canada. (1981). CHASS: Canadian Census Analyser. Retrieved from Census Subdivision: Calgary: http://dc1.chass.utoronto.ca.ezproxy.lib.ryerson.ca/cgibin/census/1981/displayCensusCSD.cgi

Statistics Canada. (1991). CHASS: Canadian Census Analyser. Retrieved from Census Subdivision: Calgary: http://dc1.chass.utoronto.ca.ezproxy.lib.ryerson.ca/cgibin/census/1991/displayCensusCSD.cgi 
Statistics Canada. (1996). CHASS: Canadian Census Analyser. Retrieved from Census Subdivisions: Calgary: http://dc1.chass.utoronto.ca.ezproxy.lib.ryerson.ca/cgibin/census/1996/displayCensusCSD.cgi

Statistics Canada. (2001). CHASS: Canadian Census Analyser. Retrieved from Census Subdivision: Calgary: http://dc1.chass.utoronto.ca.ezproxy.lib.ryerson.ca/cgibin/census/2001/displayCensusCSD.cgi

Statistics Canada. (2006). CHASS: Canadian Census Analyser . Retrieved from Census Subdivision: Calgary: http://dc1.chass.utoronto.ca.ezproxy.lib.ryerson.ca/cgibin/census/2006/displayCensusCSD.cgi

Statistics Canada. (2011). CHASS: 2011 National Household Survey (NHS). Retrieved from Census Subdivision: Calgary: http://dc1.chass.utoronto.ca.ezproxy.lib.ryerson.ca/cgibin/census/2011nhs/displayCensus.cgi? year=2011\&geo $=$ csd

Statistics Canada. (2011). CHASS: Canadian Census Analyser. Retrieved from Census Subdivision: Calgary: http://dc1.chass.utoronto.ca.ezproxy.lib.ryerson.ca/cgibin/census/2011/displayCensus.cgi?year=2011\&geo $=$ csd

Statistics Canada. (2011). Homeownership and Shelter Costs in Canada: National Household Survey, 2011. Ottawa: Statistics Canada.

Statistics Canada. (2015, 01 12). Population and Dwelling Counts. Retrieved from Statistics Canada: http://www12.statcan.gc.ca/census-recensement/2011/dp-pd/hlt-fst/pd-pl/TableTableau.cfm? $\mathrm{T}=301 \& \mathrm{~S}=3 \& \mathrm{O}=\mathrm{D}$

Taylor, Z., Burchfield, M., \& Kramer, A. (2014). Alberta Cities At the Crossroads: Urban Development Challenges and Opportunities in Historical and Comparative Perspective. Calgary: University of Calgary - School of Public Policy.

The City of Calgary. (2009). Municipal Development Plan . Calgary: The City of Calgary.

The City of Calgary: Geodemographics. (2014). Calgary Snapshots 2014. Calgary: City of Calgary.

Thompson, D. (2013). Suburban Sprawl: Exposing Hidden Costs, Identifying Innovations. Ottawa: Sustainable Prosperity .

Tomalty, R., \& Alexander, D. (2005). Smart Growth in Canada: Implementation of a Planning Concept. Ottawa: CMHC.

Tomalty, R., \& Curran, D. (2003). Living it up: the wide range of support for smart growth in Canada promises more livable towns and cities. Alternatives Journal, 10-18.

Tomalty, R., \& Haider, M. (2008). Housing Affordability and Smart Growth in Calgary. Calgary: The City of Calgary. 
Tomalty, R., \& Haider, M. (2012). The 2012 Smart Growth Report: Progress Towards Smart Growth in Canada. Ottawa: CMHC.

United Nations. (1987). Report of the World Commission on Environment and Development: "Our Common Future.". United Nations.

United States Environmental Protection Agency. (2015). Smart Growth Principles. Retrieved from Smart Growth: http://www.epa.gov/smartgrowth/about_sg.htm 